\title{
Healthy Drinks with Lovely Colors: Phenolic Compounds as Constituents of Functional Beverages
}

\author{
Teresa Pinto $^{1}$ (D) and Alice Vilela ${ }^{2, *(D)}$ \\ 1 CITAB, Centre for the Research and Technology of Agro-Environmental and Biological Sciences, \\ Department of Biology and Environment, School of Life Sciences and Environment, \\ University of Trás-os-Montes and Alto Douro, 5000-801 Vila Real, Portugal; tpinto@utad.pt \\ 2 CQ-VR, Chemistry Research Centre, Department of Biology and Environment, \\ School of Life Sciences and Environment, University of Trás-os-Montes and Alto Douro, \\ 5000-801 Vila Real, Portugal \\ * Correspondence: avimoura@utad.pt
}

Citation: Pinto, T.; Vilela, A. Healthy Drinks with Lovely Colors: Phenolic Compounds as Constituents of Functional Beverages. Beverages 2021, 7, 12. https://doi.org/10.3390/ beverages7010012

Academic Editor: María Rosa Pérez-Gregorio

Received: 21 December 2020

Accepted: 9 February 2021

Published: 23 February 2021

Publisher's Note: MDPI stays neutral with regard to jurisdictional claims in published maps and institutional affiliations.

Copyright: (c) 2021 by the authors. Licensee MDPI, Basel, Switzerland. This article is an open access article distributed under the terms and conditions of the Creative Commons Attribution (CC BY) license (https:// creativecommons.org/licenses/by/ $4.0 /)$.

\begin{abstract}
Consumers increasingly prefer and seek food and beverages, which, due to their natural characteristics, bring health benefits, both in the prevention of diseases and in their curative power. In this way, the production of nutraceutical foods and beverages gains more and more importance in the market. On the other hand, and because the eyes also eat, producing attractive foods due to their color, texture, appearance, and sensory characteristics is a permanent challenge in the food industry. Being able to gather healthy and attractive items in a single food is an even greater challenge. The long list of benefits associated with phenolic compounds, such as antioxidant, anticancer, anti-inflammatory, and antiaging properties, among others, fully justifies their use in the enrichment of various food products. Thus, in this review, we propose to summarize the potential use of phenolic compounds used as ingredients of pleasant and functional beverages.
\end{abstract}

Keywords: nutraceutical properties; human health; phenolic compounds; fermented beverages; nonfermented beverages

\section{Introduction}

As many researchers state, color is an important product-intrinsic sensory cue when it comes to establishing people's anticipations regarding the likely taste and flavor of a food or a drink. Several researchers now suggest that our experience of taste and flavor is determined by the expectations that we generate before tasting, especially when we can inspect a drink visually before deciding on whether, or not, to buy or taste it [1,2]. Brain and visual system development are intimately linked to the acquisition of food and drink, and contemporary neuroscience demonstrates that the sight of appealing food or drink is a powerful cue for the brain, especially the brain of a hungry person [3].

Consequently, many of us often have our sense of taste tricked by the sense of sight. We expect the food and drink to taste like what we see. When the color of a drink is different from what was expected, our brain tells us that it will taste different. Scientific studies proved that we frequently judge food quality based on colors to identify the taste, which ultimately affects our purchase decision. Taste buds play a significant role in determining the six basic tastes-sweet, salty, sour, bitter, umami, and fat [4]. Signals will be sent from taste buds to the brain that will interpret taste and flavor. The taste transduction mechanism is schematized in Figure 1. The apical surface of the taste receptor cell contains channels and $\mathrm{G}$ protein-coupled receptors that are activated by chemical stimuli. The basolateral surface contains voltage-gated $\mathrm{Na}^{+}, \mathrm{K}^{+}$, and $\mathrm{Ca}^{2+}$ channels, as well as all the mechanisms for synaptic transmission mediated by serotonin. The ion $\mathrm{Ca}^{2+}$ acts as a 2 nd messenger and the increase in cytoplasmatic $\mathrm{Ca}^{2+}$ occurs due to the activation of voltage-gated $\mathrm{Ca}^{2+}$ channels or due to their release from intracellular stores. This second messenger causes 
synaptic vesicles to fuse and release their transmitter onto receptors on primary sensory neurons, directly to the gustatory cortex, in the brain $[5,6]$.

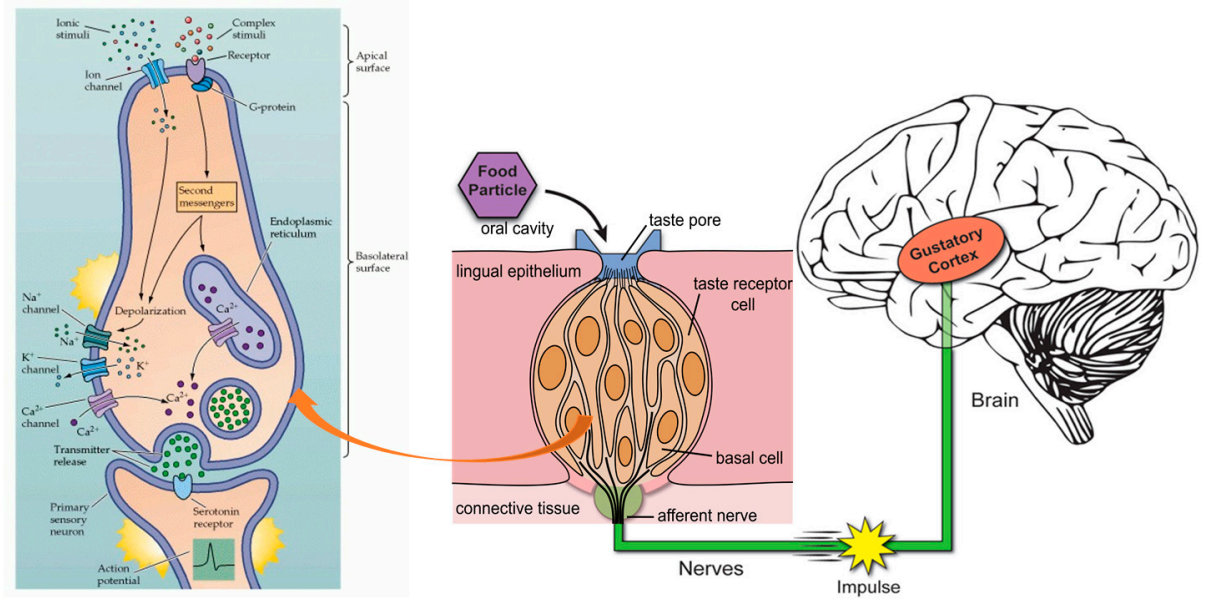

Figure 1. Transduction mechanisms in a generic taste cell. Adapted from Purves et al. [5] and Vera and Wooding [6].

However, before we eat or drink, we will look at the food or drink first, and signals are sent to the brain which interprets the taste of the food or beverage before we consume it, predetermining the expected taste and flavor. The detection of shape and color is done by the eyes. Light enters the eye through the cornea, passing through the pupil at the center of the iris (Figure 2). The lens adjusts to focus the light on the retina, where it appears upside down and backward. Receptor cells on the retina send information via the optic nerve to the visual cortex. When light falls on the retina, it creates a photochemical reaction in the rods and cones at the back of the retina. The reactions then continue to the bipolar cells, the ganglion cells, and eventually to the optic nerve [7], which sends the information to the brain (Figure 2).

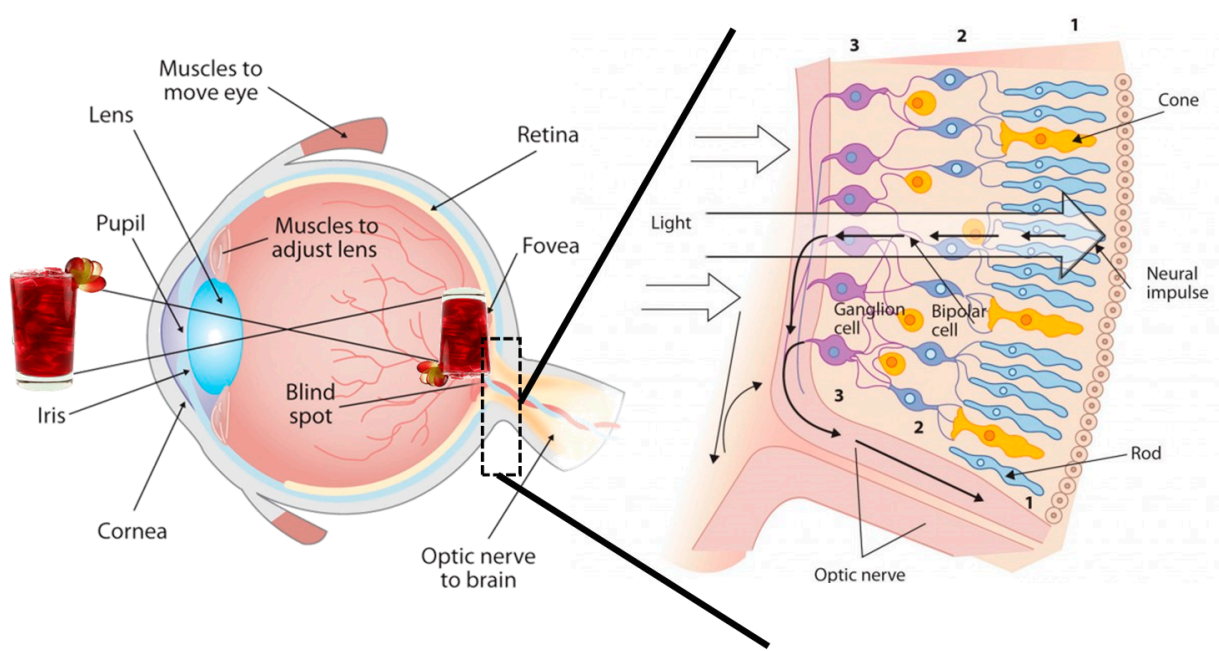

Figure 2. Anatomy of the human eye and the retina with its specialized cells. (1) Light entering the eye triggers the photochemical reaction in rods and cones of the retina; (2) chemical reaction activates bipolar cells; (3) information is sent to the visual cortex via the thalamus. Retrieved and adapted from Stangor and Walinga [8].

Moir [9] was the first to report that people's perception of taste and flavor could change merely by changing the color of food. Later, many researchers studied this issue, trying to comprehend how vision influences taste and flavor. Some of the researchers found 
that changing the hue and/or intensity of the color added to a beverage could influence the perceived identity and/or intensity of the flavor. Many people will say that a cherryflavored drink tastes like lime if colored green, while perceiving it to taste like orange if colored orange [10,11]. Zampini et al. [11] found that supertasters were significantly less influenced by the inappropriate coloring of a beverage than were medium tasters. Medium tasters were, also, less influenced than the non-tasters (Figure 3).
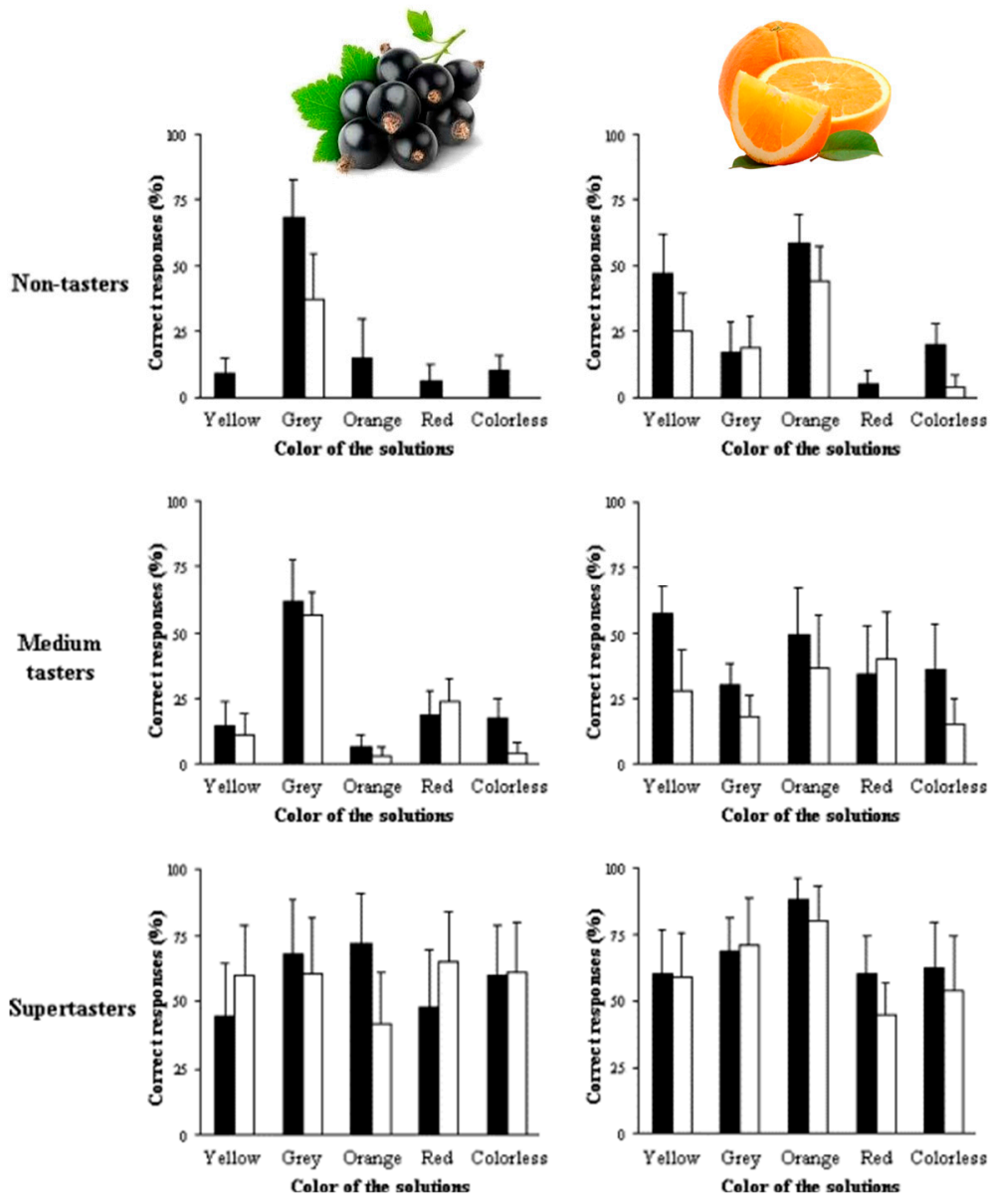

Figure 3. Mean percentage of correct flavor identification responses in blackcurrant and orange solutions, for the three groups of participants (non-tasters, medium tasters, and supertasters). Black columns are solutions where fruit acids had been added; white columns are solutions without fruit acids. Adapted from Zampini et al. [11].

Thus, humans tend to associate colors with food and connect these colors to certain tastes and flavors. For example, black-colored food is usually perceived as bitter or having a burnt flavor. Bright colors, like yellow, are perceived as sweet or sour; red can be perceived as spicy. Several studies, conducted over the last thirty-five years, show that the majority of us do indeed match basic tastes to colors in a nonrandom way that is regular across individuals and consistent over time [12-15].

The phenolic compounds, which naturally occur in many fruit-based beverages, may positively or negatively affect their sensory traits, with important impacts on color, perceived taste and flavor, and astringency. Polyphenols originate from plants due to their secondary metabolism and accumulate in plant organs like leaves, fruits, roots, and stems. They are essential to plant life as they provide defense against harmful microorganisms and make plants unpalatable to predators $[16,17]$. They also present different color palettes, that may influence, as has been mentioned before, our taste and flavor perception (Figure 4). 


\begin{tabular}{|c|c|c|c|c|c|c|}
\hline \multicolumn{7}{|c|}{ POLYPHENOLS } \\
\hline $\begin{array}{l}\text { Flavonoids } \\
\text { (Responsible for } \\
\text { plant colors) }\end{array}$ & $\begin{array}{l}\text { Flavonols } \\
\text { In the skins of } \\
\text { F\&V }\end{array}$ & $\begin{array}{l}\text { Flavones } \\
\text { In yellow and } \\
\text { green F\&V }\end{array}$ & $\begin{array}{l}\text { Flavanones } \\
\text { In citrus fruits }\end{array}$ & $\begin{array}{l}\text { Flavanols } \\
\text { AKA Catechins }\end{array}$ & $\begin{array}{l}\text { Anthocyanins } \\
\text { Give red, blue, } \\
\text { and purple } \\
\text { colors }\end{array}$ & $\begin{array}{l}\text { Isoflavones } \\
\text { Similar to } \\
\text { estrogen }\end{array}$ \\
\hline Phenolic Acids & \multicolumn{6}{|c|}{ Derivatives of benzoic and cinnamic acid. Found a lot in plant foods. } \\
\hline Stilbenes & \multicolumn{6}{|c|}{ Less common in the diet. They are synthesized by plants in response to injury or infection. } \\
\hline Lignans & \multicolumn{6}{|c|}{ Diphenolic compounds. Some are considered Phytoestrogens. } \\
\hline
\end{tabular}

Figure 4. Different polyphenol colors and correspondent fruits and vegetables (F\&V—fruits and vegetables; AKA—also known as). Retrieved from Emerson Ecologics [18].

Adequate consumption of phenolic compounds may offer health benefits [19]. The consumption of fruit-based beverages, fermented or not, and rich in phenolic compounds and presenting a lovely color, has also been related to healthy diets, such as the Mediterranean diet, and to the prevention of chronic diseases since they present antioxidant properties [19]. After the consumption of a fruit beverage rich in phenolic compounds, only a select number of phenolic compounds is absorbed into the circulatory system via the small intestine [20]. The absorptive process is dependent on molecular complexity, size, charge, food matrix, and the presence of other drugs [21]. A huge amount of the ingested phenolics is metabolized by the gut microbiota, generating small molecules (phenolic acids or lactone structures) that may be absorbed and exercise physiological effects [22-24]. Evidence suggests that these metabolites have health benefits for humans [25]. Phenolic compounds act as reducing or metal-chelating agents, hydrogen donors, and singlet oxygen quenchers [26]. Moreover, phenolic compounds can prevent disease through mechanisms that differ from the antioxidant function, such as cellular signaling, gene expression, and modulation of enzymatic activity [27]. Furthermore, the consumption of diets rich in phenolic compounds may also modulate human gut microbiota [28].

However, which beverages can be considered beneficial to health by consumers? Do they associate the colors of food and beverages with the presence of beneficial compounds? Most of the research on the psychological influence of color on judgments of taste/flavor intensity has been conducted with beverages because it is easier to manipulate the level of color in solutions than in solid foods [28] and there is a motivation to produce red fruit beverages like grape juice or grape nectar for their important nutritional properties [29,30]. Red coloring in beverages and foods also appears to be a particularly good inducer of sweetness. It seems that humans may have internalized the environmental association between sweetness and redness in ripe fruits [31].

Therefore, taking all this into account, in this review, we aim to overview the potential use of phenolic compounds, natural or man-made, as ingredients of joyful and functional beverages.

\section{The Traditional Mediterranean Diet}

Before the mid-1960s, the common diet pattern in countries in the Mediterranean Sea basin, such as Italy and Greece, was recognized as a "Mediterranean diet" [32]. However, providing an accurate definition of this type of diet is not easy, as it varies with the cultural, social, and religious habits of each country, and with time [33,34].

Recognized as Intangible Cultural Heritage by the United Nations Educational, Scientific and Cultural Organization (UNESCO) in 2013 (UN), the Mediterranean diet is traditionally recognized for its varied palette of colors, rich in aromas and memories, but mainly because it is an extremely healthy cuisine given its complete nutritional composition of essential macronutrients and micronutrients [35-37]. Indeed, several studies report that the inhabitants of the Mediterranean region with a Mediterranean dietary pattern had a low incidence of lifestyle diseases, namely, cardiovascular disease, when compared to the American population [32,38-41]. 
Consequently, what is so special about the Mediterranean diet? It should be noted that this diet pattern has evolved, as mentioned by Radd-Vagenas et al. [33], who defined the historical timeline of Mediterranean diets: ancient, "traditional", and modern. Thus, considered the cradle of civilization, the Mediterranean basin was influenced by ancient civilizations, and the food and food patterns of the time were shaped by the culture of each people, the historical period, the economy, and the climatic conditions, among other factors [42]. Two important influences should be mentioned in the model of ancient Mediterranean cuisine: the influence of Arabic/Islamic culture, as it includes a greater variety of fruits and vegetables (pomegranate, almonds, spinach, eggplant, citrus fruits), barley, wheat, rice, and spices; as well as Cristóvão Colombo's voyages to America, from which various vegetables, tomatoes, potatoes, corn, and pepper emerged [36,43].

However, a healthy diet would always be based on meats (in moderation), fish, fruits, vegetables, cereals, without forgetting the role of drinks, where the base would be water, but, in moderate quantities, it would also include the consumption of wine [43]. Figure 5 shows the food and beverage groups consumed in the Mediterranean dietary pattern.

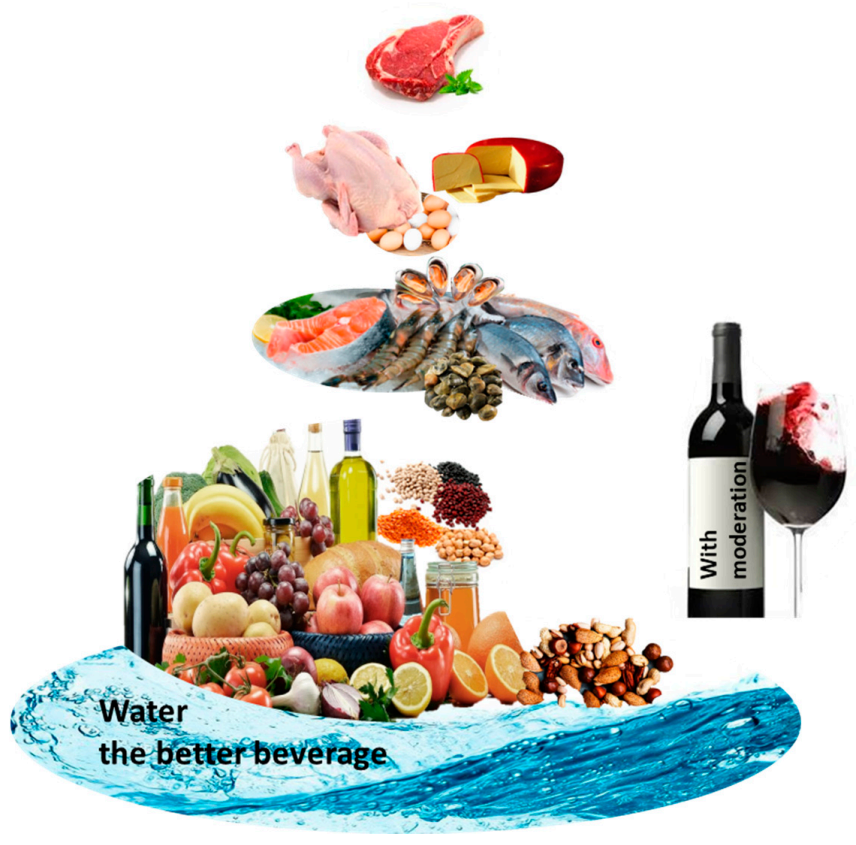

Figure 5. The Mediterranean diet pyramid.

The "traditional" Mediterranean diet can be referred to as belonging to a time before the globalization of ultra-processed foods and the modern era of industrial agriculture [44]. It is based on plants that grow in the Mediterranean region, including olives [45-47].

In the different patterns of the Mediterranean diet, olive oil is a common factor, either for its beneficial properties or for being associated with the seasoning of various raw dishes, such as salads that allow the consumption of large quantities of vegetables and legumes, or for its use in cooked food. The use of spices and herbs is recommended, avoiding the excessive use of salt. Thus, the basic Mediterranean diet includes the daily consumption of vegetables, fruit, beans, bread, cereals, potatoes, nuts, seeds, dairy products, and olive oil, and the weekly consumption of fish, shellfish, poultry, and eggs and, once a week or less, meat. Regarding drinks, water is the base that should be consumed daily. The consumption of tea (infusion of Camellia sinensis) and infusions of aromatic herbs (sage, siderites, lemon, verbena, chamomile, mint) is recommended. Infusions of several herbs present a huge source of phenolic compounds, as can be seen in Table 1. For instance, lemon balm (Melissa officinalis) presents a total phenolic concentration of $133 \mathrm{mg}$ GAE/g DW and it can be used to ease the negative mood effects of laboratory-induced psychological stress [48]. 
Table 1. Total phenolic content expressed in mg of gallic acid equivalents per g of dry weight (mg GAE/DW), and total flavonoid content in milligrams of chlorogenic acid equivalents per gram of leaf dry weight (mg CAE/g DW) of herbal infusions. Adapted from Herrera et al. [49].

\begin{tabular}{ccc}
\hline Herbal Infusions & $\begin{array}{c}\text { Total Phenolic Content } \\
\text { (mg GAE/DW) }\end{array}$ & $\begin{array}{c}\text { Total Flavonoid Content } \\
\text { (mg CAE/g DW) }\end{array}$ \\
\hline Lemon Balm & $133.3 \pm 6.9$ & $127.6 \pm 2.7$ \\
Linden & $33.9 \pm 3.2$ & $11.8 \pm 0.1$ \\
Passionflower & $14.9 \pm 1.2$ & $2.0 \pm 0.3$ \\
St. John's Wort & $72.9 \pm 2.5$ & $2.8 \pm 2.4$ \\
Valerian & $9.8 \pm 0.3$ & $5.1 \pm 0.0$ \\
Black Tea & $21.5 \pm 0.4$ & $2.9 \pm 0.2$ \\
Green Tea & $61.0 \pm 1.3$ & $14.5 \pm 0.6$ \\
Red Tea & $30.0 \pm 1.6$ & $51.0 \pm 3.2$ \\
Boldo & $62.1 \pm 0.2$ & $3.7 \pm 0.1$ \\
Chamomile & $6.0 \pm 0.4$ & $6.4 \pm 0.6$ \\
Fennel & $19.9 \pm 0.8$ & $9.0 \pm 0.2$ \\
Green Anise & $15.9 \pm 0.4$ & $14.0 \pm 0.7$ \\
Pennyroyal & $16.2 \pm 0.7$ & $3.5 \pm 0.1$ \\
Senna & $6.8 \pm 0.1$ & $17.8 \pm 0.5$ \\
Hawthorn & $29.2 \pm 1.0$ & $2.0 \pm 0.1$ \\
Horsetail & $29.9 \pm 1.1$ & $18.4 \pm 2.2$ \\
Olive Tree & $26.7 \pm 0.9$ & $41.5 \pm 0.9$ \\
Rosemary & $47.4 \pm 1.3$ & $35.9 \pm 1.6$ \\
Thyme & $40.3 \pm 0.7$ & \\
\hline
\end{tabular}

Other beverages, like coffee, and fermented beverages, such as wine, should be consumed in moderation, and, particularly wine, preferably with meals $[45,50]$. Thus, the Mediterranean diet is a plant-based diet particularly rich in phytochemicals named polyphenols and flavonoids (Table 2) [51-54], and also full of color, from the yellow-green of olive oil to the dark red of fruit, fruit juices, and wine, as can be seen in Table 3 that exemplifies a one-day summer menu based on the "traditional" Mediterranean diet.

Table 2. Different classes of flavonoids and dietary sources. Adapted from $[53,54]$.

\begin{tabular}{|c|c|c|}
\hline Flavonoid & Name & Dietary Source \\
\hline \multirow{2}{*}{ Flavone } & Chrysin & Fruit skins \\
\hline & Apigenin & Parsley, celery \\
\hline Flavanone & $\begin{array}{l}\text { Naringin, naringenin, taxifolin, eriodictyol, } \\
\text { hesperidin, and isosakuranetin }\end{array}$ & Citrus, grapefruit, lemons, and oranges \\
\hline \multirow{3}{*}{ Flavonol } & Kaempferol & Leek, broccoli, endives, grapefruit, black tea \\
\hline & Quercetin & $\begin{array}{l}\text { Onion, lettuce, broccoli, tomato, tea, berries, apples, } \\
\text { olive oil, cranberry }\end{array}$ \\
\hline & Rutin & Buckwheat, citrus, red pepper, red wine, tomato skin \\
\hline \multirow{3}{*}{ Flavononol } & Engeletin and astilbin & White grape skin \\
\hline & Genistin & Soybean \\
\hline & Taxifolin & Fruits \\
\hline Isoflavone & Genistein, daidzin, and daidzein & Soybean \\
\hline Flavanol & $\begin{array}{c}\text { (+)-Catechin, } \\
(+) \text {-Gallocatechin, } \\
(-) \text {-Epicatechin, } \\
(-) \text {-Epigallocatechin, }(-) \text {-Epicatechin gallate, } \\
(-) \text {-Epigallocatechin gallate }\end{array}$ & Tea \\
\hline
\end{tabular}


Table 2. Cont.

\begin{tabular}{ccc}
\hline Flavonoid & Name & Dietary Source \\
\hline \multirow{2}{*}{ Anthocyanidin } & Epigenidin & Stored fruits \\
\cline { 2 - 3 } & Cyanidin & Cherry, raspberry, strawberry, grapes \\
\cline { 2 - 3 } & Delphinium and pelargonidin & Dark fruits \\
\hline
\end{tabular}

Table 3. One-day menu sample of the Mediterranean diet. Adapted from Radd-Vagenas et al. [33].

Meal
Breakfast
$\begin{gathered}\text { Bread topped with grated fresh tomato, crumbled feta, } \\ \text { dried oregano, and drizzled with extra virgin olive oil } \\ \text { Herbal tea or boiled Greek coffee }\end{gathered}$
$\begin{gathered}\text { Mediterranean penne with courgettes and eggplant, } \\ \text { mozzarella cheese, olives, basil leaves. Seasoned with } \\ \text { olive oil, and accompanied with red wine }\end{gathered}$
$\begin{gathered}\text { Ratatouille with tomato sauce or kale risotto with } \\ \text { pumpkin or fish, rice, olive oil, and natural spices } \\ \text { White wine }\end{gathered}$
Winner
Fresh fruit in season or fruit juices
Nuts
Dried fruit, e.g., figs, raisins

Many of the polyphenol-rich elements of the Mediterranean diet are fruits, where the total phenol concentration may range between $158.8(\mu \mathrm{mol} / \mathrm{g})$ in cranberry to $7.5(\mu \mathrm{mol} / \mathrm{g})$ in grapefruit (Table 4). Several of these fruits can be eaten in their natural form, or in the form of multi-fruit juices which present a high total phenol antioxidant index (PAOXI).

Table 4. Total phenol content and total phenol antioxidant index (PAOXI) of fruits. Adapted from [53,55].

\begin{tabular}{ccc}
\hline Fruit & Total Phenols $(\mu \mathbf{m o l} / \mathbf{g})$ (Dry Weight) & $\begin{array}{c}\text { Total PAOXI } \times \mathbf{1 0}^{-3} \text { (a) } \\
\text { (Dry Weight) }\end{array}$ \\
\hline Apple & 34.1 & 110 \\
Avocado & 12.7 & 60.5 \\
Banana & 42.3 & 108 \\
Blueberry & 62.0 & 273 \\
Cantaloupe & 8.1 & 32.4 \\
Cherry & 52.3 & 523 \\
Cranberry & 158.8 & 212 \\
Grape (white) & 52.3 & 262 \\
Grape (red) & 63.7 & 351 \\
Grapefruit & 7.5 & 39.5 \\
Lemon & 19.6 & 67.6 \\
Melon (honeydew) & 11.4 & 36.8 \\
Nectarine & 12.3 & 64.7 \\
Orange & 18.9 & 55.6 \\
Peach & 27.9 & 60.7 \\
Pear & 41.4 & 81.2 \\
\hline
\end{tabular}


Table 4. Cont.

\begin{tabular}{ccc}
\hline Fruit & Total Phenols $(\mu \mathrm{mol} / \mathbf{g})$ (Dry Weight) & $\begin{array}{c}\text { Total PAOXI } \times \mathbf{1 0}^{-3} \text { (a) } \\
\text { (Dry Weight) }\end{array}$ \\
\hline Pineapple & 11.9 & 44.1 \\
Plum & 58.2 & 116 \\
Strawberry & 72.3 & 603 \\
Watermelon & 19.5 & 44.3 \\
\hline
\end{tabular}

(a) Ratio of phenol concentration $(\mu \mathrm{mol} / \mathrm{kg})$ to the $\mathrm{IC}_{50}$ value $(\mu \mathrm{M})$.

Despite having observed a change in eating habits in countries that were the basis for the Mediterranean diet, due to economic development, high rates of urbanization, and the influence of American fast-food culture [33,52], nowadays, more and more of the world's population tries to practice a healthy diet, but with a great concern for the sustainability of the planet. Thus, the Mediterranean diet, favoring the consumption of fresh food, produced locally and according to a sustained production system, and consumed in a pleasant and familiar environment with associated physical activity, is associated with a healthy lifestyle.

\section{Classification of Phenolic Antioxidants}

Phenolic compounds are classified as primary antioxidants [53] and originate from one of the main classes of secondary metabolites in plants. They have antioxidant properties through several mechanisms: (i) the ability to remove free radicals and inhibit the formation of reactive species during the normal course of metabolism; (ii) preventing the occurrence of damage to lipids, proteins, and nucleic acids; and (iii) preventing consequent cell damage and death [56]. Thus, they are commonly associated with preventing the development of cardiovascular diseases, neurodegenerative diseases, autoimmune diseases, diabetes, and cancer [57-62].

Depending on their origin, phenolic antioxidants can be classified as natural or artificial. Figure 6 shows the classification of phenolic antioxidants.

\section{Phenolic Antioxidants}

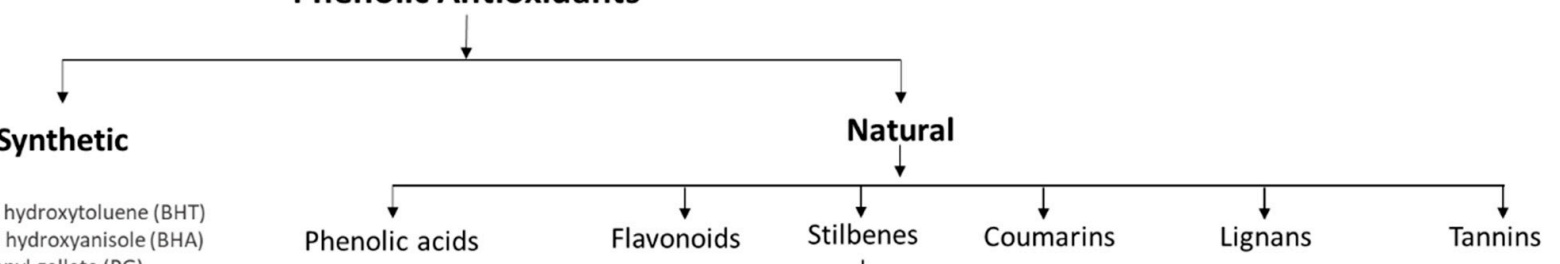

Butylated hydroxytoluene (BHT) Butylated hydroxyanisole (BHA) Propyl gallate (PG) Tectiary-butylhydroquinone (TBHQ)
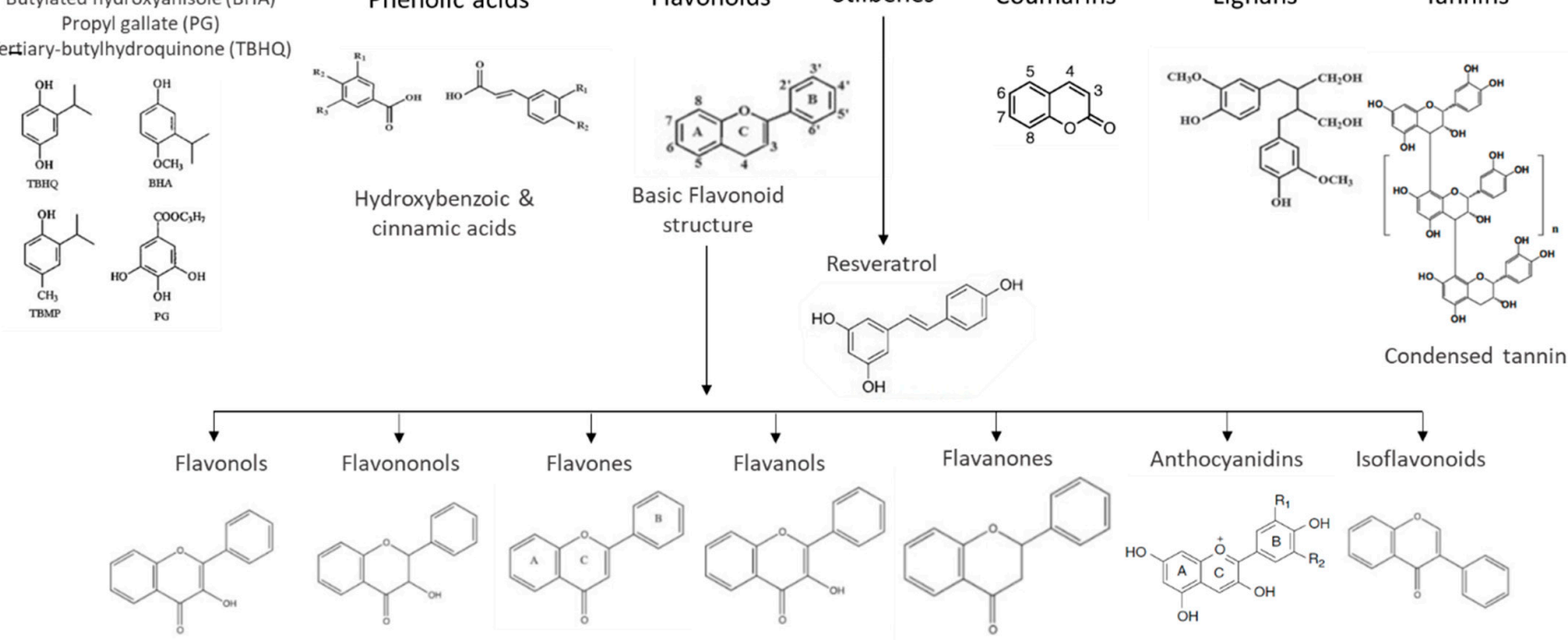

Figure 6. Phenolic antioxidants classification. Adapted from Shahidi and Ambigaipalan [53]. 
Antioxidants used in foods and beverages are intended to prevent their deterioration and to increase shelf life. However, the appearance and characteristics of each food or drink, such as color and sensory proprieties, must be kept unchanged [63]. Furthermore, they must be easy to apply and economical. The safety of food additives is verified through the application of standard methodologies by regulatory authorities, namely, the European Food Safety Authority (EFSA) or the United States Food and Drug Administration (FDA), which validate the use of substances and in which concentrations [64].

\subsection{Natural Phenolic Antioxidants in Beverages}

Natural antioxidants can be obtained from plants (fruits, legumes, and vegetables), mushrooms, and algae, and are classified as phenolic compounds, vitamins, and carotenoids [65-67].

In recent years, there has been a growing preference for natural phenolic antioxidants over artificial ones, fundamentally due to the increasing demand by consumers for functional foods and beverages with the addition of natural additives, which maintain their nutritional properties and flavor [68]. Besides, this trend results, according to the same authors, from the preference currently given to natural phenolic antioxidants in food stabilization, and the restrictions applied by the responsible entities on the use of synthetic phenolic antioxidants $[69,70]$.

Natural phenolic antioxidants have a great diversity of structures, in which the basic monomer of polyphenols is the phenolic ring [71]. They are divided into several classes, the most representative of which are flavonoids and phenolic acids. For their part, flavonoids are further divided into flavones, flavanones, flavonols, flavanols, isoflavones, and phenolic acids and are generally classified into hydroxybenzoic and hydroxycinnamic acids [72].

Stilbenes are a group of phenolic compounds that share a similar chemical structure to flavonoids (Figure 6). Trans-resveratrol is one of the most recognized stilbenes, present mostly in glycosylated forms. Red wine, as well as the red grapes that originate this fermented drink, are rich in resveratrol. Several studies show that moderate consumption of red wine leads to a reduction in the development of cardiovascular diseases and atherosclerotic plaques, and provides neuroprotective, antidiabetic, anti-inflammatory, antioxidant, anticarcinogenic, and antiviral activity [73-75].

When analyzing different types of wines, namely, whites, rosés, and reds, Paixão et al. [76] showed that red wine had significantly higher phenolic levels than the rosé and white wines, and consequently exhibited the highest antioxidant power. According to Fiori et al. [77], the highest concentration of resveratrol is higher in red wine than in white wine because it is present in the skin and seeds of grapes. Thus, the different phenolic composition of wines is related to the grape variety, as well as the edaphoclimatic conditions of the region where the grapes are produced, cultural practices, the stage of ripeness [78,79], maceration [80,81], yeasts used in the vinification process [82], and other winemaking conditions [83].

Cordova and Sumpio [84] also concluded that red wine has more health-promoting activity than beer or spirits due to its richer content of phenolic compounds, hence the increased interest in the nutraceutical value of wines.

Additionally, herbal teas and infusions are rich in natural antioxidants, mainly flavonoids: theaflavins, bis-flavanols, and fulvic acids. Their consumption has increased because they are recognized as having anticariogenic properties and antimicrobial and anticancer activity $[85,86]$. McCarthy et al. [87] studied the antioxidant potential of plant extracts and compared them with synthetic antioxidants and vitamin E, incorporating them in pork. The catechins present in tea were shown to be more effective in terms of their antioxidant power, compared to butylated hydroxyanisole (BHA) and butylated hydroxytoluene (BHT), and antioxidant activity was evaluated through the thiobarbituric acid reactive substance assay (TBARS assay—reactive species of thiobarbituric acid). 
The market for natural antioxidants is growing and new products have appeared on the market with a healthy image, namely, smoothies, functional drinks, and yogurts with green tea, grape seed, lemon balm, and aloe vera, among others [68].

It is important to note that there are natural antioxidants that have lower antioxidant activity than their synthetic equivalents, which can lead to the use of a higher dosage, causing toxicity reactions [88]. Thus, the intensification of toxicity studies of these compounds is necessary to know the limits of their use.

\subsection{Synthetic Phenolic Antioxidants in Beverages}

Several synthetic phenolic antioxidants (SPAs) are widely used in industrial and commercial products, but only a few can legally be added to food products [89]. Thus, with a common molecular structure in which the phenolic rings are replaced by alkyls hindered in the ortho position [70], butylated hydroxyanisole (BHA), butylated hydroxytoluene $(\mathrm{BHT})$, propyl gallate (PG), and tertiary-butylhydroquinone (TBHQ) are commonly used as food antioxidants [90]. However, BHA and BHT are the antioxidants most used as additives in food products [91,92].

The poor stability of natural antioxidants has increased the number of SPAs that are preferred for use in food and beverages to prevent and delay lipid oxidation reactions, preventing the formation of foreign flavors and undesirable chemical compounds, such as aldehydes, ketones, and organic acids, and prolong the shelf life of products [93].

SPAs can be used alone or in combination. Thus, BHA is commonly found in dry cereals, derived from potatoes, in cooked foods (boiled or fried and desserts), and in drinks [90,94]. In food supplements, condiments, spices, chewing gum, and oils, BHT can be used alone or in combination with BHA or TBHQ [95]. As a preservative, TBHQ is used in edible animal fats, meat products, and unsaturated vegetable oils [96]. Propyl gallate has been used in the food industry as a stabilizer in fatty foods and as an additive in mayonnaise, fats, edible fats, and baked goods [97].

The presence of a wide range of undesirable compounds in foods and beverages has made the area of food safety increasingly relevant, to provide the population with the necessary high-quality food. Therefore, the growing concern about using safe and environmentally friendly food products has recently led to the realization of several studies to find out if the use of SPAs in food and beverages is safe for health. Their conclusions are contradictory. In some studies, SPAs revealed antimutagenic and antitumor properties [98-102] but, in others, allergic reactions, including asthma and hives [103], toxic effects in some animal tissues [104], liver toxicity, endocrine-disrupting effects, and even carcinogenicity [93,105-107] were reported, questioning their use [70,108].

This issue generated concern on the part of the governments of the European Union and most countries to create legislation that regulates the use of SPAs, either individually or in mixtures, as the market for combined natural or synthetic phenolic antioxidants is expected to have a growth rate of around 5\% by 2023 [109]. In the European Union, the use of certain SPAs has been restricted and has even been banned in soft drinks [89].

\section{Phenolic Antioxidants and Human Health}

Although, in the present day, the main world health concern is COVID-19, the global pandemic caused by the SARS-COV-2 virus, other diseases also kill millions of people every year. Globally, the number of deaths due to cardiovascular diseases (CVDs) between 1990 and 2017 increased from 12.3 to 17.79 million (Figure 7A) [110]. The World Health Organization (WHO) estimates that $60 \%$ of all CVDs occur now in developing nations (Figure 7B) [110], where a recent increase in the incidence of CVDs has been driven by higher obesity rates. The global economic burden of these diseases is projected to rise from an estimated USD 863 billion in 2010 to an estimated USD 1044 billion by 2030 [111]. This increase is expected to be most acutely felt in nations such as India, Egypt, and the republics of the former Soviet Union (Figure 7C) [110]. 

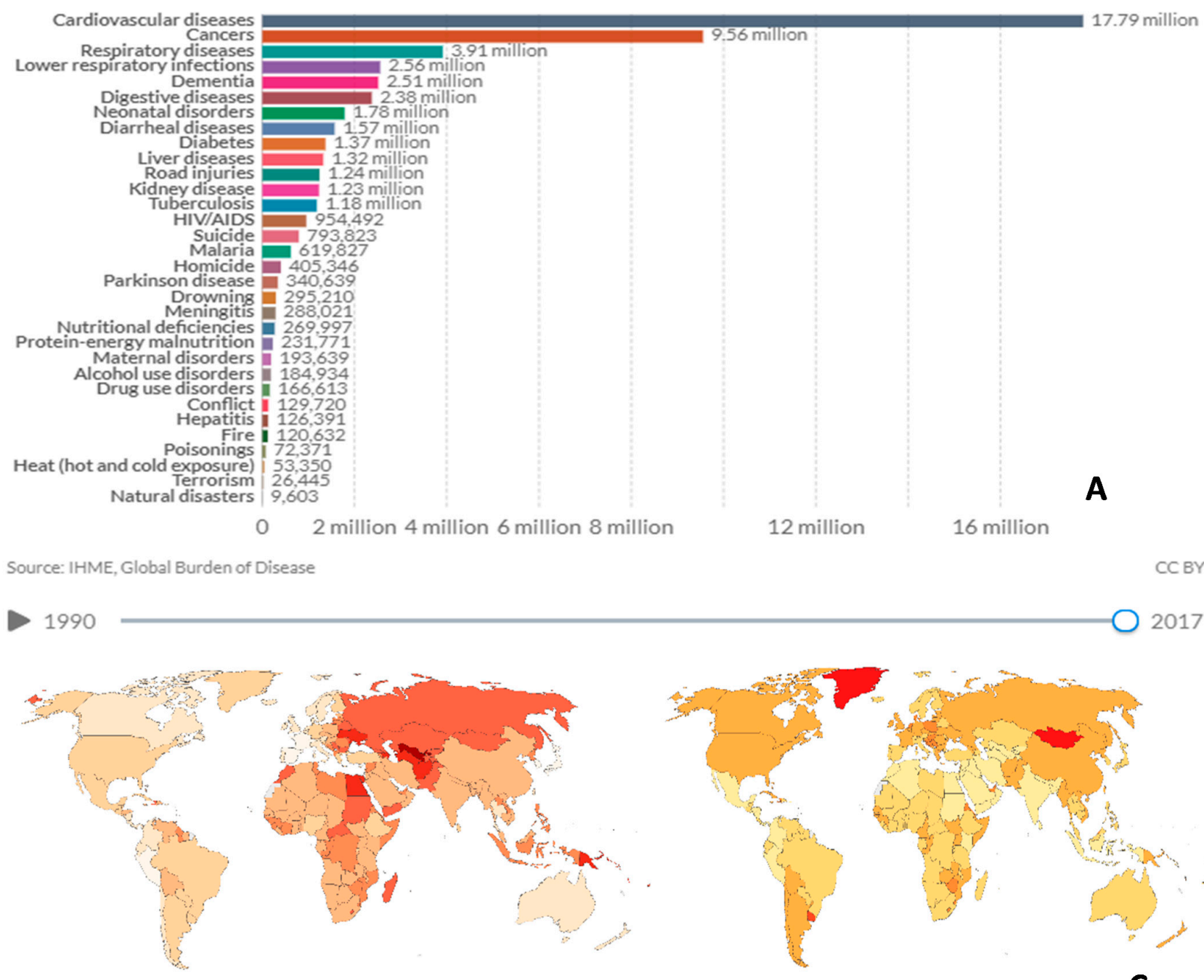

B

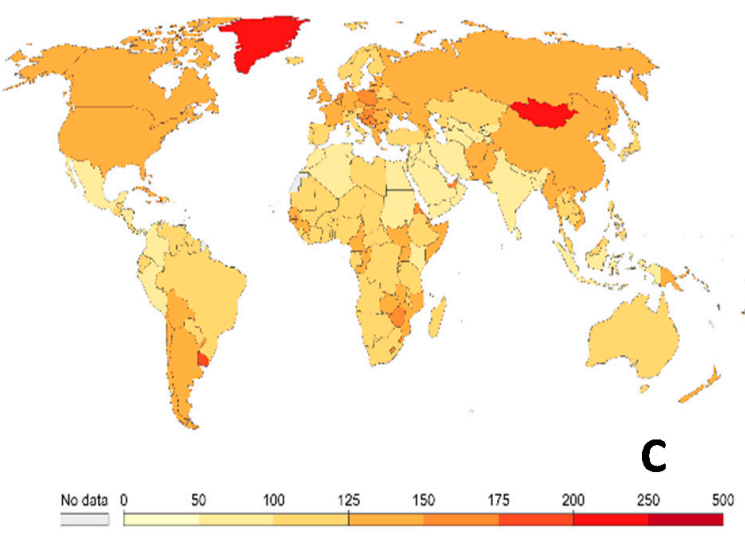

Figure 7. The number of deaths by cause from 1990 to 2017 (A); Death rate from cardiovascular disease (B). The death rate from cancer (C). Annual number of deaths per 100,000 people (data from 2017). To allow comparisons between countries and over time, this metric is age standardized. Data retrieved from Our World in Data [110] and World Heart Federation [111].

Longevity is considered by the United Nations as one of the biggest achievements of this century, and a major social transformation [112]. Evidence supports that diets rich in plant-based foods can be associated with a lessened risk of cardiovascular disease (CVD) [113], thus promoting longevity. The current nutritional guidelines for the prevention of CVDs include a diet high in fruits, vegetables, whole grains, nuts, legumes, and non-tropical vegetable oils, and are based on the Mediterranean diet, which is rich in phenolic compounds [114]. Various phenolic compounds may exercise beneficial effects by reducing risk factors for the onset of CVDs and age-related disease (ARD) that involves the so-called "inflamm-aging" process $[115,116]$. The association of phenolic compounds with the reduced incidence of CVDs was studied by Lutz et al. [117] who state that these compounds can promote a healthy aging process, retarding or even inhibiting the risk factors involved in CVDs, mainly high cholesterol levels, high blood pressure, diabetes, urinary isoprostanes, low-density lipoprotein (LDL) oxidation, platelet aggregation, and inflammatory status, among others [118-121]. All these health-related issues contribute to atherothrombosis and the consequent occurrence of CVDs [122]. Table 5 summarizes some of the main beverages that possess polyphenolic compounds, their structures, and bioactivities. 
Table 5. Alcoholic and nonalcoholic beverages, their main phenolic compounds present and indicated bioactivities.

\begin{tabular}{ccc}
\hline Beverages & Main Phenolics & Indicated Bioactivities \\
\hline $\begin{array}{c}\text { Tea and infusions } \\
\text { (Camelia sinensis and other } \\
\text { plants) }\end{array}$ & $\begin{array}{c}\text { Pure catechins, ((-)-epicatechin } \\
\text { (EC), (-)-epicatechin gallate (ECG), } \\
(-) \text {-epigallocatechin (EGC), and } \\
(-) \text {-epigallocatechin gallate } \\
(\text { EGCG)), and phenolic acids, } \\
\text { thearubigins, theaflavins, } \\
\text { theasinensins, and } \\
\text { polyhydroxylated flavan-3-ols. }\end{array}$ & $\begin{array}{c}\text { Potential for use of EGCG in human } \\
\text { Induction of the suppression of } \\
\text { tumor cell proliferation, stimulation } \\
\text { of apoptosis, promotion of } \\
\text { progestogen, and changes in } \\
\text { testosterone release. }\end{array}$ \\
& $\begin{array}{c}\text { Reduce the risk of Parkinson's } \\
\text { disease. }\end{array}$ \\
\hline
\end{tabular}

Fruit juices

(Tree fruits, citrus fruits, and dark fruits)

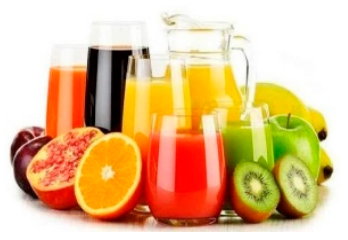

Polyphenols, most of which are

flavonoids, present mainly in the ester and glycoside forms.
Lower the incidence of degenerative diseases such as cancer, arthritis, arteriosclerosis, heart disease, inflammation, brain dysfunction, and acceleration of the aging process.

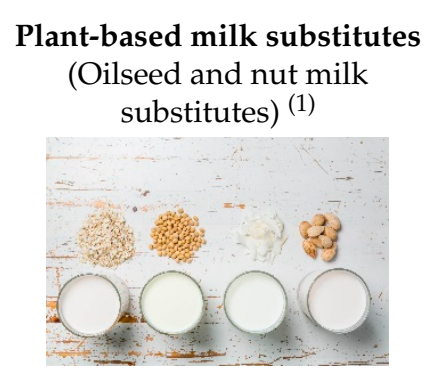

Tocopherol (mainly $\alpha$-tocopherol) and, to a lesser extent, $\gamma$-tocopherol. Isoflavone glycosides and their derivatives.

Phenolic acids, namely syringic, vanillic, caffeic, ferulic, $p$-coumaric, and $p$-hydroxybenzoic.

Catechol is the predominant volatile phenolic compound found in coffee (after roasting), followed by 4-ethylguaiacol, 4-ethyl catechol, pyrogallol, quinol, and 4-vinyl catechol.

Catechin, rutin, ferulic acid, o-dihydroxybenzene, chlorogenic acid, caffeic acid, gallic acid, and protocatechuic acid.

\section{Cocoa drinks}

(Cocoa liquor, cocoa emulsions)

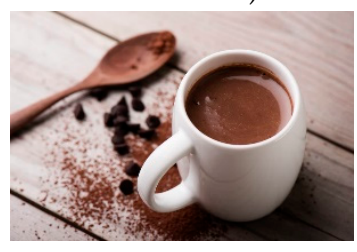

Epicatechin, gallocatechin, and epigallocatechin. Phenolics, procyanins, anthocyanins, and flavone and flavonol glycosides such as luteolin-7-O-glucoside and quercetin-3-O-arabinoside.
Help to support the cardiovascular system. Lowers cholesterol levels and can reduce menopause symptoms due to their elevated content of isoflavones, which are a class of chemical known as "phytoestrogens".

[53,126-128]

Their high antioxidant content makes them preventative agents against ovarian, breast, stomach, prostate, and lung cancer.

Chlorogenic acid has potential cardiovascular benefits related to the lowering of blood pressure, endothelial function improvement, low-density lipoprotein cholesterol oxidation, and nitric oxide

bioavailability prevention of metabolic syndrome, including vascular endothelial function impairment, obesity, and diabetes.

Consumption of cocoa reduces the risk of cardiovascular disease. Extracts prepared from cocoa powder and cocoa beans were shown to exhibit antihyperglycemic effects. 
Table 5. Cont.

\begin{tabular}{|c|c|c|c|}
\hline Beverages & Main Phenolics & Indicated Bioactivities & Ref. \\
\hline $\begin{array}{c}\text { Beer } \\
\text { (Composition of phenolic } \\
\text { compounds depends on the } \\
\text { brand and country of origin) }\end{array}$ & $\begin{array}{c}\text { Gallic acid, protocatechuic acid, } \\
(+) \text {-catechin, vanillic acid, caffeic } \\
\text { acid, syringic acid, (-)-epicatechin, } \\
\text { p-coumaric acid, and ferulic acid. } \\
\text { The major free phenolic acids in } \\
\text { beers are } m-, p \text {-and } o \text {-coumaric and } \\
\text { ferulic. } \\
\text { Sinapic, vanillic, chlorogenic, } \\
\text { homovanillic, } p \text {-hydroxybenzoic, } \\
\text { 2,6- and 3,5-dihydroxybenzoic, } \\
\text { syringic, gallic, protocatechuic, and } \\
\text { caffeic acids. }\end{array}$ & $\begin{array}{l}\text { Positive effect on plasma lipid } \\
\text { profile and plasma antioxidant } \\
\text { capacity. } \\
\text { Increase bile volume and bile acid } \\
\text { concentrations. }\end{array}$ & {$[136,137]$} \\
\hline $\begin{array}{l}\text { Wine } \\
\text { (Depends on the grape variety, } \\
\text { the winemaking process, } \\
\text { wine-fermenting yeast strain, } \\
\text { among others) }\end{array}$ & $\begin{array}{l}\text { The most common flavonoids in } \\
\text { wine are flavonols (quercetin, } \\
\text { kaempferol, and myricetin), } \\
\text { flavan-3-ols (catechin and } \\
\text { epicatechin), tannins, and } \\
\text { anthocyanins (cyanin). } \\
\text { Nonflavonoids comprise stilbenes, } \\
\text { hydroxycinnamic acids, and } \\
\text { benzoic acids. }\end{array}$ & $\begin{array}{l}\text { Decrease the levels of lipid } \\
\text { peroxidation and a lower the } \\
\text { incidence of certain types of cancer. } \\
\text { The moderate consumption of red } \\
\text { wine has a relatively higher benefit } \\
\text { in the prevention of atherosclerosis } \\
\text { and coronary heart disease (CHD). } \\
\text { Inhibit low-density lipoprotein } \\
\text { (LDL) oxidation, increase } \\
\text { antioxidative capacity, and } \\
\text { modulate vascular function by } \\
\text { inducing vasodilation through } \\
\text { increased production of nitric } \\
\text { oxide (NO). }\end{array}$ & {$[82,138,139]$} \\
\hline
\end{tabular}

(1) Almond (Prunus dulcis), cashew (Anacardium occidentale), coconut (Cocos nucifera), hazelnut (Corylus), peanut (Arachis hypogaea), sesame (Sesamum indicum), soy (Glycine max), tiger nut (Cyperus esculentus), oat (Avena sativa), rice (Oryza sativa), hemp (Cannabis sativa), and walnut (Juglans). ${ }^{(2)}$ Vanillic, ferulic, and $p$-coumaric acids were the dominant free phenolic acids in Spanish, German, and Danish brands.

Cancer is also a worldwide menace; it is the second leading cause of death in developed countries (Figure 7A) and is increasing in developing countries. Humanity has been trying to find better and cheaper treatments with fewer side effects, to reduce the incidence of the disease and its consequent mortality [140].

Phenolic compounds have been described as exhibiting anticancer activity in vitro and in vivo [53,141-144] (Table 5). Their efficacy varies from one compound to another, which is due to the variations in their structures as well as their molecular targets [145]. Structure vs. activity relationship studies have identified the involvement of aromatic rings and hydroxylic groups in antitumor activity $[146,147]$. Additionally, reports suggest that molecules with a larger number of hydroxylic groups displayed better anticancer activity compared to others with no hydroxylic groups or compounds with-OCH3 fractions [145]. In addition, studies comparing the efficacy of cinnamic and benzoic acids in inhibiting cancer cell growth showed that cinnamic acids that contain an unsaturated propionic acid side chain are superior anticancer agents $[146,147]$. Therefore, benzoic and cinnamic acid derivatives possessing hydroxyl substitutions could be used naturally or in pharmaceutical formulas to prevent cancer cell proliferation [145].

The mechanisms of action for the antitumor activity of phenolic compounds include stopping the proliferation of cancer cells [148]; inducing tumor cellular apoptosis [53,86,123,124,149] (Table 5); and preventing tumor cell migration and invasionso-called metastasis [53,129-131,150].

Another concern, in terms of wellbeing, especially in the 21st century, as life expectancy, according to the WHO, is projected to reach 73 years by 2025 [151], is neurodegenerative diseases such as Alzheimer's and Parkinson's. Many thousands of people born at the end of the 20th century will live through the 21st century and see the advent of the 
22nd century. People will live longer, but will they really have "quality of life"? Evidence supports that oxidative stress is involved in the pathophysiology of neurodegenerative diseases. Oxidative stress can induce neuronal damages and modulate intracellular signaling, ultimately leading to neuronal death by apoptosis or necrosis [152].

The pathogenesis of diseases such as Alzheimer's or Parkinson's is multifactorial, with a complex combination of genetic and nongenetic components $[53,125,152]$. Most of these cases are nongenetic or sporadic. According to the World Health Report [152], inflammation, glutamatergic toxicity, dysfunction of mitochondrial activity and the ubiquitin/proteasome system, activation of apoptosis pathways, elevation of iron and nitric oxide, and alteration of the homeostasis of antioxidants/oxidation are the main mechanisms involved in neurodegenerative pathologies. Green tea, which is particularly rich in flavonoids [86], including catechins and their derivatives, could have a beneficial role in reducing the risk of Parkinson's disease [53,153]. The catechol-like structure of catechins competitively inhibits uptake by the presynaptic or vesicular transporters of the metabolite product of 1-methyl-4-phenylpyridinium ions (MPP+), also presenting a catechol-like structure. This competition protects dopaminergic neurons against MPTP/MPP+-induced injury [154].

Alzheimer's disease pathology progresses gradually via anatomically connected brain regions. The progressive pathology is due to the direct transfer of amyloid- $\beta 1-42$ oligomers $(\mathrm{oA} \beta)$ between connected neurons [155]. Concerning Alzheimer's disease, there are several in vitro studies demonstrating that green tea extract may protect neurons from amyloid $\beta$-induced damage [156,157].

Oxidative stress or inflammation can also be the cause of chronic diseases such as diabetes, insulin resistance, urinary tract infections, chronic obstructive pulmonary disease, and rheumatoid arthritis $[53,158,159]$. These chronic diseases, like arthritis (also considered an autoimmune disease with unknown etiology), may accelerate cardiovascular complications [147].

Phenolic compounds have been described as able to promote a decrease in hyperglycemia, improve acute insulin secretion and insulin sensitivity [160], prevent rheumatoid arthritis [161], and have antiadhesive activity against uropathogenic bacteria, preventing urinary tract infections [162].

So, all the health menaces described above have a huge impact, not only on personal health, but also in terms of people's productivity, wellbeing, and, ultimately, quality of life and happiness.

\section{Digestion, Catabolism, and Bioaccessibility of Beverage Phenolic Compounds}

The absorption, transportation, bioavailability, and bioactivity of polyphenols and related metabolites after food or beverage intake have been research topics of increasing interest in recent decades. The absorption and metabolism of polyphenols in the digestive tract regulate their biological properties and bioavailability, and only those released from the food/beverage matrix are digested in the small and large intestine [163]. Polyphenols occur in beverages mainly as large polymers (esters, glycosides) which cannot be absorbed in these forms and require hydrolysis by digestive enzymes or intestinal microbiota. Only 5$10 \%$ of the phenolic compounds from different fruits are bioaccessible in the small intestine, while $90 \%$ of phenolic compounds reach the large intestine, where they are catabolized by gut microbiota [164,165].

Gut microbiota convert complex polyphenols into low molecular weight compounds that can be absorbed [24] and thus are accountable for the beneficial effects of polyphenol consumption $[166,167]$. Additionally, clinical studies indicate that polyphenols are also able to express prebiotic properties, by modulating the growth of beneficial bacteria such as Bifidobacterium and Lactobacillus $[167,168]$. New products containing probiotic strains as well as polyphenol compounds as antioxidants have been launched in the market, particularly beverages based on fruits, vegetables, cereals, and soybeans $[169,170]$. Additionally, nanoencapsulation-based approaches can be used to develop beverages, which may com- 
bine the benefits of natural products with the known biological properties of phenolic compounds, without resulting in a loss of sensory or nutritional quality and increasing bioaccessibility [171].

However, as stated by Teng and Chen [172], bioaccessibility values of polyphenolic compounds should be strongly reconsidered, considering the recently identified circulating and excreted metabolites, keeping in mind the colonic metabolic products which contribute largely to their absorption, making them able to travel around the human body in the circulatory system or reach body tissues to elicit bioactive effects.

\section{Final Remarks}

Phenolic compounds may affect the sensory characteristics of food with impact on color, flavor, and astringency. This impact is important and needs to be evaluated so that health-promoting compounds are also pleasant and generally consumed. Moreover, more projects and the implementation of more research, especially for human trials, are needed to confirm the efficacy of polyphenols at the gut level.

The Mediterranean diet based on dietary patterns in the countries of the Mediterranean basin is considered healthy because it is centered on the consumption of fruits, vegetables, cereals, olive oil, fish, eggs, and meats (in moderation). Fruit juices, tea, herbal infusions, coffee, nondairy beverages, beer, and red wine are included in the diet, directly or as a by-product of vegetal origin that is processed, possibly fermented, and also may contain probiotic microorganisms valuable for gut microbiota equilibrium and polyphenol bioavailability and absorption.

The demand for this type of diet by consumers has increased, as it is associated with the prevention of cardiovascular disease, cancer, and neurodegenerative diseases, and longevity. The pharmaceutical industry has been discovering medicines that diminish some of the symptoms of these diseases. Many are still incurable, and prevention is still the best action. Prevention requires a change in lifestyle habits, especially in food and beverage consumption. Strong and already confirmed evidence suggests that a diet of food and beverages rich in polyphenols may help to prevent and control the abovementioned health issues, reducing multimorbidity and leading to a healthier and happier life.

Author Contributions: T.P. and A.V. equally contributed to the work. All authors have read and agreed to the published version of the manuscript.

Funding: This research was funded by the CQ-VR (grant number UIDB/00616/2020 and UIDP/ 00616/2020); CITAB (grant number UIDB/04033/2020); and FCT-Portugal and COMPETE and by FEDER/COMPETE/POCI-Operational Competitiveness and Internationalization Program under Project POCI-01-0145-FEDER-006958.

Informed Consent Statement: Not applicable.

Data Availability Statement: Not applicable.

Conflicts of Interest: The authors declare no conflict of interest.

\section{References}

1. Piqueras-Fizman, B.; Spence, C. Sensory expectations based on product-extrinsic food cues: An interdisciplinary review of the empirical evidence and theoretical accounts. Food Qual. Prefer. 2015, 40, 165-179. [CrossRef]

2. Vilela, A.; Cosme, F. Drink Red: Phenolic Composition of Red Fruit Juices and Their Sensorial Acceptance. Beverages 2016, 2, 29. [CrossRef]

3. Spence, C.; Okajima, K.; Cheok, A.D.; Petit, O.; Michel, C. Eating with our eyes: From visual hunger to digital satiation. Brain Cogn. 2016, 110, 53-63. [CrossRef]

4. Vilela, A.; Inês, A.; Cosme, F. Is wine savory? Umami taste in wine. SDRP J. Food Sci. Technol. 2016, 1. [CrossRef]

5. Purves, D.; Augustine, G.J.; Fitzpatrick, D. (Eds.) Taste Receptors and the Transduction of Taste Signals. In Neuroscience, 2nd ed.; Sinauer Associates: Sunderland, MA, USA, 2001. Available online: https://www.ncbi.nlm.nih.gov/books/NBK11148/ (accessed on 5 December 2020).

6. Vera, L.; Wooding, S. Taste: Links in the Chain from Tongue to Brain. Front. Young Minds 2017, 5, 33. [CrossRef]

7. Mannu, G.S. Retinal phototransduction. Neurosciences 2014, 19, 275-280. [PubMed] 
8. Stangor, C.; Walinga, J. Chapter 5. Sensing and Perceiving. In Introduction to Psychology, 1st ed.; Stangor, C., Walinga, J., Eds.; BCcampus: Victoria, BC, Canada, 2014; ISBN 978-1-77420-005-6.

9. Moir, H.C. Some observations on the appreciation of flavour in foodstuffs. J. Soc. Chem. Industry 1936, 55, 145-148. [CrossRef]

10. Zampini, M.; Sanabria, D.; Phillips, N.; Spence, C. The multisensory perception of flavor: Assessing the influence of color cues on flavor discrimination responses. Food Qual. Prefer. 2007, 18, 975-984. [CrossRef]

11. Zampini, M.; Wantling, E.; Phillips, N.; Spence, C. Multisensory flavor perception: Assessing the influence of fruit acids and color cues on the perception of fruit-flavored beverages. Food Qual. Prefer. 2008, 19, 335-343. [CrossRef]

12. O'Mahony, M. Gustatory responses to non-gustatory stimuli. Perception 1983, 12, 627-633. [CrossRef]

13. Koch, C.; Koch, E.C. Preconceptions of taste based on color. J. Psychol. 2003, 137, 233-242. [CrossRef] [PubMed]

14. Tomasik-Krótki, J.; Strojny, J. Scaling of sensory impressions. J. Sens. Stud. 2008, 23, 251-266. [CrossRef]

15. Wan, X.; Woods, A.T.; van den Bosch, J.; McKenzie, K.J.; Velasco, C.; Spence, C. Cross-cultural differences in crossmodal correspondences between tastes and visual features. Front. Psychol Cogn. 2014, 5, 1365. [CrossRef]

16. Vogt, T. Phenylpropanoid Biosynthesis. Mol. Plant. 2010, 3, 2-10. [CrossRef] [PubMed]

17. Oliveira, L.L.; Carvalho, M.V.; Melo, L. Health-promoting and sensory properties of phenolic compounds in food. Rev. Ceres 2014, 61, 764-779. [CrossRef]

18. Emerson Ecologics. Polyphenols-The Star of the Mediterranean Diet. 2018. Available online: https://edu.emersonecologics. com/2018/02/28/polyphenols-star-mediterranean-diet/ (accessed on 19 December 2020).

19. Cory, H.; Passarelli, S.; Szeto, J.; Tamez, M.; Mattei, J. The Role of Polyphenols in Human Health and Food Systems: A Mini-Review. Front. Nutr. 2018, 5, 87. [CrossRef] [PubMed]

20. D'Archivio, M.; Filesi, C.; Vari, R.; Scazzocchio, B.; Masella, R. Bioavailability of the polyphenols: Status and controversies. Int. J. Mol. Sci. 2010, 11, 1321-1342. [CrossRef]

21. Domínguez-Avila, J.A.; Wall-Medrano, A.; Velderrain-Rodríguez, G.R.; Chen, O.; Salazar-López, N.J.; Robles-Sánchez, M.; González-Aguilar, G.A. Gastrointestinal interactions, absorption, splanchnic metabolism, and pharmacokinetics of orally ingested phenolic compounds. Food Funct. 2017, 8, 15-38. [CrossRef]

22. Day, A.J.; Canada, F.J.; Diaz, J.C.; Kroon, P.A.; Mclauchlan, R.; Faulds, C.B.; Plumb, G.W.; Morgan, M.R.; Williamson, G. Dietary flavonoid and isoflavone glycosides are hydrolysed by the lactase site of lactase phloridzin hydrolase. FEBS Lett. 2000, 468, 166-170. [CrossRef]

23. Aura, A.M. Microbial metabolism of dietary phenolic compounds in the colon. Phytochem. Rev. 2008, 7, 407-429. [CrossRef]

24. Espín, J.C.; González-Sarrías, A.; Tomás-Barberán, F.A. The gut microbiota: A key factor in the therapeutic effects of (poly) phenols. Biochem. Pharmacol. 2017, 139, 82-93. [CrossRef]

25. Del Rio, D.; Rodriguez-Mateos, A.; Spencer, J.P.; Tognolini, M.; Borges, G.; Crozier, A. Dietary (poly)phenolics in human health: Structures, bioavailability, and evidence of protective effects against chronic diseases. Antioxid. Redox Signal. 2013, 18, 1818-1892. [CrossRef]

26. Kasote, D.M.; Katyare, S.S.; Hegde, M.V.; Bae, H. Significance of antioxidant potential of plants and its relevance to therapeutic applications. Int. J. Biol. Sci. 2015, 11, 982-991. [CrossRef]

27. Yahfoufi, N.; Alsadi, N.; Jambi, M.; Matar, C. The Immunomodulatory and Anti-Inflammatory Role of Polyphenols. Nutrients 2018, 10, 1618. [CrossRef]

28. Peredo-Lovillo, A.; Romero-Luna, H.E.; Jiménez-Fernández, M. Health promoting microbial metabolites produced by gut microbiota after prebiotics metabolism. Food Res. Int. 2020, 136, 109473. [CrossRef]

29. Spence, C.; Wan, X.; Woods, A.; Velasco, C.; Deng, J.; Youssef, J.; Deroy, O. On tasty colours and colourful tastes? Assessing, explaining, and utilizing cross-modal correspondences between colours and basic tastes. Flavour 2015, 4, 23. [CrossRef]

30. Burin, V.M.; Falcão, L.D.; Gonzaga, L.V.; Fett, R.; Rosier, J.P.; Bordignon-Luiz, M.T. Colour, phenolic content and antioxidant activity of grape juice. Ciência e Tecnologia de Alimentos 2010, 30, 1027-1032. [CrossRef]

31. Spence, C. Multisensory flavour perception. Curr. Biol. 2013, 23, R365-R369. [CrossRef] [PubMed]

32. Keys, A.; Menotti, A.; Karvonen, M.J.; Aravanis, C.; Blackburn, H.; Buzina, R.; Djordjevic, B.S.; Dontas, A.S.; Fidanza, F.; Keys, M.H.; et al. The diet and 15-year death rate in the seven countries study. Am. J. Epidemiol. 1986, 124, 903-915. [CrossRef] [PubMed]

33. Radd-Vagenas, S.; Kouris-Blazos, A.; Singh, M.F.; Flood, V.M. Evolution of Mediterranean diets and cuisine: Concepts and definitions. Asia Pac. J. Clin. Nutr. 2017, 26, 749-763. [CrossRef]

34. Mazzocchi, A.; Leone, L.; Agostoni, C.; Pali-Schöll, I. The Secrets of the Mediterranean Diet. Does [Only] Olive Oil Matter? Nutrients 2019, 11, 2941. [CrossRef]

35. Sofi, F.; Abbate, R.; Gensini, G.F.; Casini, A. Accruing evidence on benefits of adherence to the Mediterranean diet on health: An updated systematic review and meta-analysis. Am. J. Clin. Nutr. 2010, 92, 1189-1196. [CrossRef] [PubMed]

36. Altomare, R.; Cacciabaudo, F.; Damiano, G.; Palumbo, V.D.; Gioviale, M.C.; Bellavia, M.; Tomasello, G.; Lo Monte, A.I. The Mediterranean Diet: A History of Health. Iranian J. Publ. Health 2013, 42, 449-457.

37. Sanchez-Villegas, A.Z.; Zazpe, I. A healthy-eating model called mediterranean diet. In Prevention of Cardiovascular Disease through the Mediterranean Diet; Sánchez-Villegas, A., Sánchez-Tainta, A., Eds.; Academic Press: Cambridge, MA, USA, 2018; pp. 1-24. [CrossRef] 
38. Willett, W.C.; Sacks, F.; Trichopoulou, A.; Drescher, G.; Ferro-Luzzi, A.; Helsing, E.; Trichopoulos, D. Mediterranean diet pyramid: A cultural model for healthy eating. Am. J. Clin. Nutr. 1995, 61 (Suppl. 6), 1402S-1406S. [CrossRef] [PubMed]

39. Leaf, A. Dietary prevention of coronary heart disease: The Lyon Diet Heart Study. Circulation 1999, 99, 733-735. [CrossRef] [PubMed]

40. de Lorgeril, M.; Salen, P. The Mediterranean diet in secondary prevention of coronary heart disease. Clin. Investig. Med. 2006, 29, 154-158. [CrossRef]

41. Estruch, R.; Ros, E.; Salas-Salvadoó, J.; Covas, M.I.; Corella, D.; Arós, F.; Gómez-Gracia, E.; Ruiz-Gutiérrez, V.; Fiol, M.; Lapetra, J.; et al. Primary Prevention of a Cardiovascular Disease with a Mediterranean Diet Supplemented with Extra-Virgin Olive Oil or Nuts. N. Engl. J. Med. 2018, 378, e34. [CrossRef]

42. Vasilopoulou, E.; Georga, K.; Joergensen, M.; Naska, A.; Trichopoulou, A. The antioxidant properties of Greek foods and the flavonoid content of the Mediterranean menu. Curr. Med. Chem. Immunol. Endocr. Metab. Agents 2005, 5, 33-45. [CrossRef]

43. Salas-Salvadó, J.; Huetos-Solano, M.D.; García-Lorda, P.; Bulló, M. Diet and dietetics in al-Andalus. Br. J. Nutr. 2006, 96, S100-S104. [CrossRef]

44. Weichselbaum, D.E.; Benelam, B. Synthesis Report No 6: Traditional Foods in Europe; European Food Information Resource (EuroFIR) Consortium: Brussels, Belgium; Institute of Food Research; Norwich Research Park: Norwich, UK, 2009; ISBN 09076676782009.

45. Kromhout, D.; Keys, A.; Aravanis, C.; Buzina, R.; Fidanza, F.; Giampaoli, S.; Jansen, A.; Menotti, A.; Nedeljkovic, S.; Pekkarinen, M.; et al. Food consumption patterns in the 1960s in seven countries. Am. J. Clin. Nutr. 1989, 49, 889-894. [CrossRef] [PubMed]

46. Alberti-Fidanza, A.; Fidanza, F. Mediterranean adequacy index of Italian diets. Public Health Nutr. 2004, 7, 937-941. [CrossRef]

47. Trichopoulou, A. Mediterranean diet, traditional foods, and health: Evidence from the Greek EPIC cohort. Food Nutr. Bull. 2007, 28, 236-240. [CrossRef]

48. Kennedy, D.O.; Little, W.; Scholey, A.B. Attenuation of Laboratory-Induced Stress in Humans after Acute Administration of Melissa officinalis (Lemon Balm). Psychosom. Med. 2004, 66, 607-613. [CrossRef]

49. Herrera, T.; Aguilera, Y.; Rebollo-Hernanza, M.; Bravoa, E.; Beníteza, V.; Martínez-Sáezb, N.; Arribasc, S.M.; Castillo, M.D.; Martín-Cabrejasa, M.A. Teas and herbal infusions as sources of melatonin and other bioactive non-nutrient components. LWT 2018, 89, 65-73. [CrossRef]

50. Kouris-Blazos, A.; Itsiopoulos, C. Low all-cause mortality despite high cardiovascular risk in elderly Greek-born Australians: Attenuating potential of diet? Asia Pac. J. Clin. Nutr. 2014, 23, 532-544. [CrossRef] [PubMed]

51. Carluccio, M.A.; Calabriso, N.; Scoditti, E.; Massaro, M.; De Caterina, R. Chapter 27-Mediterranean Diet Polyphenols. In The Mediterranean Diet; Preedy, V.R., Watson, R.R., Eds.; Academic Press: Cambridge, MA, USA, 2015; pp. 291-300. [CrossRef]

52. Tyrovolas, S.; Polychronopoulos, E.; Bountziouka, V.; Zeimbekis, A.; Tsiligiani, I.; Papoutsou, S.; Gotsis, E.; Metallinos, G.; Lionis, C.; Panagiotakos, D.B. Level of adherence to the Mediterranean diet among elderly individuals living in Mediterranean Islands: Nutritional report from the MEDIS study. Ecol. Food Nutr. 2009, 48, 76-87. [CrossRef] [PubMed]

53. Shahidi, F.; Ambigaipalan, P. Phenolics and polyphenolics in foods, beverages and spices: Antioxidant activity and health effects-A review. J. Funct. Foods 2015, 18, 820-897. [CrossRef]

54. Shahidi, F.; Naczk, M. Phenolics in Food and Nutraceuticals; CRC Press: Boca Raton, FL, USA, 2004; pp. 1-558.

55. Vinson, J.A.; Su, X.; Zubik, L.; Bose, P. Phenol antioxidant quantity and quality in foods: Fruits. J. Agric. Food Chem. 2001, 49, 5315-5321. [CrossRef]

56. Zhang, Y.; Seeram, N.P.; Lee, R.; Feng, L.; Heber, D. Isolation and identification of strawberry phenolics with antioxidant and human cancer cell antiproliferative properties. J. Agric. Food Chem. 2008, 56, 670-675. [CrossRef] [PubMed]

57. Kaur, S.; Das, M. Functional foods: An overview. Food Sci. Biotechnol. 2011, 20, 861-875. [CrossRef]

58. Alarcón-Flores, M.I.; Romero-González, R.; Vidal, J.L.M.; Frenich, A.G. Multiclass determination of phytochemicals in vegetables and fruits by ultra high-performance liquid chromatography coupled to tandem mass spectrometry. Food Chem. 2013, 141, 1120-1129. [CrossRef] [PubMed]

59. Liu, R.H. Dietary Bioactive Compounds and Their Health Implications. J. Food Sci. 2013, 78, A18-A25. [CrossRef]

60. McCarty, M.F. Proposal for a dietary "phytochemical index". Med. Hypotheses 2004, 63, 813-817. [CrossRef]

61. Pallauf, K.; Bendall, J.K.; Scheiermann, C.; Watschinger, K.; Hoffmann, J.; Roeder, T.; Rimbach, G. Vitamin C and lifespan in model organisms. Food Chem. Toxicol. 2013, 58, 255-263. [CrossRef]

62. Zingg, J.M. Vitamin E: An overview of major research directions. Mol. Aspects Med. 2007, 28, 400-422. [CrossRef]

63. Nanditha, B.; Prabhasankar, P. Antioxidants in bakery products: A review. Crit. Rev. Food Sci. Nutr. 2009, 49, 1-27. [CrossRef]

64. Lourenço, S.C.; Moldão-Martins, M.; Alves, V.D. Antioxidants of Natural Plant Origins: From Sources to Food Industry Applications. Molecules 2019, 24, 4132. [CrossRef]

65. Sikora, E.; Cieślik, E.; Topolska, K. The sources of natural antioxidants. Acta Sci. Pol. Technol. Aliment. 2008, 7, 5-17.

66. Jayaprakasha, G.; Singh, R.; Sakariah, K. Antioxidant activity of grape seed (Vitis vinifera) extracts on peroxidation models in vitro. Food Chem. 2001, 73, 285-290. [CrossRef]

67. Carocho, M.; Barreiro, M.F.; Morales, P.; Ferreira, I.C.F.R. Adding molecules to food, pros and cons: A review on synthetic and natural food additives. Compr. Rev. Food Sci. Food Saf. 2014, 13, 377-399. [CrossRef]

68. Massini, L.; Rico, D.; Martín-Diana, A.B.; Barry-Ryan, C. Quality Markers of Functional Tomato Juice with Added Apple Phenolic Antioxidants. Beverages 2016, 2, 4. [CrossRef] 
69. Berdahl, D.R.; Nahas, R.I.; Barren, J.P. Synthetic, and natural antioxidant additives in food stabilization: Current applications and future research. In Oxidation in Foods and Beverages and Antioxidant Applications; Decker, E.A., Elias, R.J., McClements, D.J., Eds.; Woodhead Publishing: Cambridge, UK, 2010; Volume 1, pp. 272-313.

70. Liu, R.; Mabury, S.A. Synthetic Phenolic Antioxidants: A Review of Environmental Occurrence, Fate, Human Exposure, and Toxicity. Environ. Sci. Technol. 2020, 54, 11706-11719. [CrossRef]

71. Dragovicuzelac, V.; Levaj, B.; Mrkic, V.; Bursac, D.; Boras, M. The Content of Polyphenols and Carotenoids in Three Apricot Cultivars Depending on Stage of Maturity and Geographical Region. Food Chem. 2007, 102, 966-975. [CrossRef]

72. Abbas, M.; Saeed, F.; Anjum, F.M.; Afzaal, M.; Tufail, T.; Bashir, M.S.; Ishtiaq, A.; Hussain, S.; Suleria, H.A.R. Natural polyphenols: An overview. Int. J. Food Prop. 2017, 20, 1689-1699. [CrossRef]

73. Fernández-Mar, M.I.; Mateos, R.; Garcia-Parrilla, M.C.; Puertas, B.; Cantos-Villar, E. Bioactive compounds in wine: Resveratrol, hydroxytyrosol and melatonin: A review. Food Chem. 2012, 130, 797-813. [CrossRef]

74. Gambini, J.; Inglés, M.; Olaso, G.; Lopez-Grueso, R.; Bonet-Costa, V.; Gimeno-Mallench, L.; Mas-Bargues, C.; Abdelaziz, K.M.; Gomez-Cabrera, M.C.; Vina, J.; et al. Properties of Resveratrol: In Vitro and In Vivo studies about metabolism, bioavailability, and biological effects in animal models and humans. Oxid. Med. Cell Longev. 2015, 837042. [CrossRef]

75. Gea, A.; Sánchez-Tainta, A. Red Wine Moderate Consumption and at Mealtimes. In Prevention of Cardiovascular Disease through the Mediterranean Diet; Sánchez-Villegas, A., Sánchez-Tainta, A., Eds.; Academic Press: Cambridge, MA, USA, 2018; pp. 151-157. [CrossRef]

76. Paixão, N.; Perestrelo, R.; Marques, J.C.; Câmara, J.S. Relationship between antioxidant capacity and total phenolic content of red, rosé and white wines. Food Chem. 2007, 105, 204-214. [CrossRef]

77. Fiori, L.; de Faveri, D.; Casazza, A.A.; Perego, P. Grape by-products: Extraction of polyphenolic compounds using supercritical $\mathrm{CO}_{2}$ and liquid organic solvent-A preliminary investigation Subproductos de la uva: Extraccion de compuestos polifenolicos usando $\mathrm{CO}_{2}$ supercritico y disolventes organicos liquidos-Una investigacion preliminar. CyTA J. Food 2009, 7, 163-171. [CrossRef]

78. Obreque-Slier, E.; Peńa-Neira, A.; López-Solís, R.; Zamora-Marín, F.; Ricardo-da Silva, J.M.; Laureano, O. Comparative study of the phenolic composition of seeds and skins from Carménčre and Cabernet Sauvignon grape varieties (Vitis vinifera L.) during ripening. J. Agric Food Chem. 2010, 58, 3591-3599. [CrossRef]

79. Giuffrč, A.M. HPLC-DAD detection of changes in phenol content of red berry skins during grape ripening. Eur. Food Res. Technol. 2013, 237, 555-564. [CrossRef]

80. Budić-Leto, I.; Lovrić, T.; Pezo, I.; Gajdoš Kljusurić, J. Study of dynamics of polyphenol extraction during traditional and advanced maceration processes of the Babić grape variety. Food Technol. Biotechnol. 2005, 43, 47-53.

81. Klenar, I.; Berović, M.; Wondra, M. Phenolic compounds from the fermentation of cultivars Cabernet Sauvignon and Merlot from the Slovenian coastal region. Food Technol. Biotechnol. 2004, 42, 11-17.

82. Vilela, A. The Importance of Yeasts on Fermentation Quality and Human Health-Promoting Compounds. Fermentation 2019, 5, 46. [CrossRef]

83. Coletta, A.; Berto, S.; Crupi, P.; Cravero, M.C.; Tamborra, P.; Antonacci, D.; Daniele, P.G.; Prenesti, E. Effect of viticulture practices on concentration of polyphenolic compounds and total antioxidant capacity of Southern Italy red wines. Food Chem. 2014, 152, 467-474. [CrossRef] [PubMed]

84. Cordova, A.C.; Sumpio, B.E. Polyphenols are medicine: Is it time to prescribe red wine for our patients? Int. J. Angiol. 2009, 18, 111-117. [CrossRef]

85. Soni, R.P.; Katoch, M.; Kumar, A.; Ladohiya, R.; Verma, P. Tea: Production, Composition, Consumption and it's Potential as an Antioxidant and Antimicrobial Agent. Int. J. Food. Ferment. Technol. 2015, 5, 95-106. [CrossRef]

86. Vilela, A.; Pinto, T. Grape Infusions: The Flavor of Grapes and Health-Promoting Compounds in Your Tea Cup. Beverages 2019, 5, 48. [CrossRef]

87. McCarthy, T.L.; Kerry, J.P.; Kerry, J.F.; Lynch, P.B.; Buckley, D.J. Evaluation of the antioxidant potential of natural food/plant extracts as compared with synthetic antioxidants and vitamin E in raw and cooked pork patties. Meat Sci. 2001, 58, 45-52. [CrossRef]

88. Bártíková, H.; Skálová, L.; Valentova, K.; Matoušková, P.; Szotáková, B.; Martin, J.; Kvita, V.; Boušová, I. Efect of oral administration of green tea extract in various dosage schemes on oxidative stress status of mice in vivo. Acta Pharm. 2015, 65, 65-73. [CrossRef]

89. Cacho, J.I.; Campillo, N.; Viñas, P.; Hernández-Córdoba, M. Determination of synthetic phenolic antioxidants in soft drinks by stir-bar sorptive extraction coupled to gas chromatography-mass spectrometry. Food Addit. Contam. Part A 2015, 32, 665-673. [CrossRef] [PubMed]

90. Makahleh, A.; Saad, B.; Bari, M.F. Synthetic phenolics as antioxidants for food preservation. In Handbook of Antioxidants for Food Preservation; Shahidi, F., Ed.; Woodhead Publishing Ltd.: Cambridge, UK, 2015; pp. 51-78. [CrossRef]

91. Furia, T.E. CRC Handbook of Food Additives, 2nd ed.; CRC Press: Boca Raton, FL, USA, 1980; Volume 2, p. 424. ISBN 0849305438.

92. Nieva-Echevarría, B.; Manzanos, M.J.; Goicoechea, E.; Guillén, M.D. 2,6-Di-tert-butyl-hydroxytoluene and its metabolites in foods. Compr. Rev. Food Sci. Food Saf. 2015, 14, 67-80. [CrossRef] [PubMed]

93. Lanigan, R.S.; Yamarik, T.A. Final report on the safety assessment of BHT. Int. J. Toxicol. 2002, 21 (Suppl. 2), 19-94. [CrossRef]

94. Dolatabadi, J.E.N.; Kashanian, S. A review on DNA interaction with synthetic phenolic food additives. Food Res. Int. 2010, 43, 1223-1230. [CrossRef] 
95. Lavagnini, I.; Urbani, A.; Magno, F. Overall calibration procedure via a statistically based matrix-comprehensive approach in the stir-bar sorptive extraction-thermal desorption-gas chromatography-mass spectrometry analysis of pesticide residues in fruit-based soft drinks. Talanta 2011, 83, 1754-1762. [CrossRef] [PubMed]

96. Kashanian, S.; Dolatabadi, J.E.N. DNA binding studies of 2-tert-butylhydroquinone (TBHQ) food additive. Food Chem. 2009, 116, 743-747. [CrossRef]

97. Zurita, J.L.; Jos, A.; Peso, A.D.; Salguero, M.; López-Artíguez, M.; Repetto, G. Ecotoxicological effects of the antioxidant additive propyl gallate in five aquatic systems. Water Res. 2007, 41, 2599-2611. [CrossRef]

98. Iverson, F. In vivo studies on butylated hydroxyanisole. Food Chem. Toxicol. 1999, 37, 993-997. [CrossRef]

99. Botterweck, A.A.M.; Verhagen, H.; Goldbohm, R.A.; Kleinjans, J.; van den Brandt, P.A. Intake of butylated hydroxyanisole and butylated hydroxytoluene and stomach cancer risk: Results from analyses in the Netherlands Cohort Study. Food Chem. Toxicol. 2000, 38, 599-605. [CrossRef]

100. Singh, B.; Mense, S.M.; Remotti, F.; Liu, X.; Bhat, H.K. Antioxidant butylated hydroxyanisole inhibits estrogen-induced breast carcinogenesis in female ACI rats. J. Biochem. Mol. Toxicol. 2009, 23, 202-211. [CrossRef]

101. Zhang, Y.; Choksi, S.; Liu, Z.-G. Butylated hydroxyanisole blocks the occurrence of tumor-associated macrophages in tobacco smoke carcinogen-induced lung tumorigenesis. Cancers 2013, 5, 1643-1654. [CrossRef]

102. Liang, X.; Tang, Y.; Duan, L.; Cheng, S.; Luo, L.; Cao, X.; Tu, B. Adverse effect of sub-chronic exposure to benzo(a)pyrene and protective effect of butylated hydroxyanisole on learning and memory ability in male Sprague-Dawley rat. J. Toxicol. Sci. 2014, 39, 739-748. [CrossRef]

103. Simon, R.A. Adverse reactions to food additives. Curr. Allergy Asthma Rep. 2003, 3, 62-66. [CrossRef]

104. Horváthová, E.; Slameňová, D.; Bonatti, S.; Abbondandolo, A. Reduction of genotoxic effects of MNNG by butylated hydroxyanisole. Neoplasma 1999, 46, 356-362. [PubMed]

105. Yang, X.; Song, W.; Liu, N.; Sun, Z.; Liu, R.; Liu, Q.S.; Zhou, Q.; Jiang, G. Synthetic phenolic antioxidants cause perturbation in steroidogenesis in vitro and in vivo. Environ. Sci. Technol. 2018, 52, 850-858. [CrossRef]

106. Dassarma, B.; Nandi, D.K.; Gangopadhyay, S.; Samanta, S. Hepatoprotective effect of food preservatives (butylated hydroxyanisole, butylated hydroxytoluene) on carbon tetrachloride-induced hepatotoxicity in rat. Toxicol. Rep. 2018, 5, 31-37. [CrossRef]

107. Pérez-Albaladejo, E.; Lacorte, S.; Porte, C. Differential toxicity of alkylphenols in JEG-3 human placental cells: Alteration of P450 aromatase and cell lipid composition. Toxicol. Sci. 2019, 167, 336-346. [CrossRef] [PubMed]

108. Valentao, P.; Fernandes, E.; Carvalho, F.; Andrade, P.B.; Seabra, R.M.; Bastos, M.L. Antioxidative properties of cardoon (Cynara cardunculus L.) infusion against superoxide radical, hydroxyl radical, and hypochlorous acid. J. Agric. Food Chem. 2002, 50, 4989-4993. [CrossRef]

109. Phenolic Antioxidant Market Research Report-Forecast to 2023. Market Research Future. Available online: https://www. marketresearchfuture.com/reports/phenolic-antioxidant-market-3937\#answer1 (accessed on 13 December 2020).

110. Our World in Data. Death Rate from Cardiovascular Disease and the Death Rate from Cancer Disease. 2017. Available online: https: / / ourworldindata.org/grapher/cardiovascular-disease-death-rates (accessed on 19 December 2020).

111. World Heart Federation. The Costs of CVD. 2020. Available online: http://www.championadvocates.org/en/championadvocates-programme/the-costs-of-cvd (accessed on 19 December 2020).

112. United Nations, Department of Economic and Social Affairs Population Division. World Population Ageing Report 2015, ST/ESA/SER.A/390; United Nations, Department of Economic and Social Affairs Population Division: New York, NY, USA, 2015.

113. Dauchet, L.; Amouyel, P.; Dallongeville, J. Fruits, vegetables and coronary heart disease. Nat. Rev. Cardiol. 2009, 6, 599-608. [CrossRef]

114. Goff, D.C., Jr.; Lloyd-Jones, D.M.; Bennett, G.; Coady, S.; D’Agostino, R.B.; Gibbons, R.; Greenland, P.; Lackland, D.T.; Levy, D.; O'Donnell, C.J.; et al. 2013 ACC/AHA guideline on the assessment of cardiovascular risk: A report of the American College of Cardiology / American Heart Association Task Force on Practice Guidelines. Circulation 2014, 129 (Suppl. 2), S49-S73. [CrossRef] [PubMed]

115. Wang, X.; Ouyang, Y.; Liu, J.; Zhu, M.; Zhao, G.; Bao, W.; Hu, F.B. Fruit and vegetable consumption and mortality from all causes, cardiovascular disease, and cancer: Systematic review and dose-response meta-analysis of prospective cohort studies. BMJ 2014, 349, g4490. [CrossRef] [PubMed]

116. Ricordi, C.; Garcia-Contreras, M.; Farnetti, S. Diet and inflammation: Possible effects on immunity, chronic diseases, and life span. J. Am. Coll. Nutr. 2015, 34, 10-13. [CrossRef]

117. Lutz, M.; Fuentes, E.; Ávila, F.; Alarcón, M.; Palomo, I. Roles of Phenolic Compounds in the Reduction of Risk Factors of Cardiovascular Diseases. Molecules. 2019, 24, 366. [CrossRef]

118. Palomo, I.G.; Marin, P.; Alarcón, M.; Gubelin, G.; Vinambre, X.; Mora, E.; Icaza, G. Patients with essential hypertension present higher levels of Se-selectin and Svcam-1 than normotensive volunteers. Clin. Exp. Hypertens 2003, 25, 517-523. [CrossRef]

119. Palomo, I.G.; Gutiérrez, C.L.; Alarcón, M.L.; Jaramillo, J.C.; Segovia, F.M.; Leiva, E.M.; Mujica, V.E.; Icaza, G.N.; Diaz, N.S.; Moore-Carrasco, R. Increased concentration of plasminogen activator inhibitor-1 and fibrinogen in individuals with metabolic syndrome. Mol. Med. Rep. 2009, 2, 253-257. [CrossRef] [PubMed]

120. Palomo, I.G.; Jaramillo, J.C.; Alarcón, M.L.; Gutiérrez, C.L.; Moore-Carrasco, R.; Segovia, F.M.; Leiva, E.M.; Mujica, V.E.; Icaza, G.; Di, N.S. Increased concentrations of soluble vascular cell adhesion molecule-1 and soluble Cd401 in subjects with metabolic syndrome. Mol. Med. Rep. 2009, 2, 481-485. [CrossRef] [PubMed] 
121. Palomo, I.G.; Moore-Carrasco, R.; Alarcón, M.L.; Rojas, A.; Espana, F.; Andrés, V.; González-Navarro, H. Pathophysiology of the proatherothrombotic state in the metabolic syndrome. Front. Biosci. 2010, 2, 194-208. [CrossRef]

122. Ruggeri, Z.M. Mechanisms initiating platelet thrombus formation. Thromb. Haemost. 1997, 78, 611-616. [CrossRef] [PubMed]

123. Khan, N.; Mukhtar, H. Green tea catechins: Anticancer effects and molecular targets. In Plant. Phenolics and Human Health; Fraga, C.G., Ed.; John Wiley \& Sons, Inc.: Hoboken, NJ, USA, 2010; pp. 1-4.

124. Kadasi, A.; Maruniakova, N.; Kolesarova, A.; Stochmalova, A.; Alexa, R.; Grossmann, R.; Sirotkin, A.V. The effect of green tea extracts on steroidogenesis, proliferation, and apoptosis in ovarian granulosa cells. Endocr. Abstr. 2014, 34, 348. [CrossRef]

125. Feskanich, D.; Ziegler, R.G.; Michaud, D.S.; Giovannucci, E.L.; Speizer, F.E.; Willett, W.C.; Coldits, G.A. Prospective study of fruit and vegetable consumption and risk of lung cancer among men and women. J. Nat. Cancer Ins. 2000, 92, 1812-1823. [CrossRef]

126. Schuler, P. Natural antioxidants exploited commercially. In Food Antioxidants; Hudson, B.J.F., Ed.; Elsevier: London, UK, 1990; pp. 99-170.

127. Rawal, G.; Yadav, S.; Nagayach, S. Phytosterols and the health. Med. Res. Chron. 2015, 2, 441-444.

128. Aydar, E.F.; Tutuncu, S.; Ozcelik, B. Plant-based milk substitutes: Bioactive compounds, onventional and novel processes, bioavailability studies, and health effects. J. Funct. Foods 2020, 70, 103975. [CrossRef]

129. Clifford, M.N.; Ramirez-Martinez, J.R. Phenols and caffeine in wet-processed coffee beans and coffee pulp. Food Chem. 1991, 40, 35-42. [CrossRef]

130. Tresserra-Rimbau, A.; Medina-Remón, A.; Estruch, R.; Lamuela-Raventós, R.M. Chapter 42-Coffee Polyphenols and High Cardiovascular Risk Parameters. In Coffee in Health and Disease Prevention; Preedy, V.R., Ed.; Academic Press: Cambridge, MA, USA, 2015; pp. 387-394. [CrossRef]

131. Yamagata, K. Do Coffee Polyphenols Have a Preventive Action on Metabolic Syndrome Associated Endothelial Dysfunctions? An Assessment of the Current Evidence. Antioxidants 2018, 7, 26. [CrossRef]

132. Keen, C.L. Chocolate: Food as medicine/medicine as food. J. Am. Coll. Nutition 2001, 20, 436S-439S. [CrossRef] [PubMed]

133. Sanchez-Rabaneda, F.; Jauregui, O.; Casals, I.; Andres-Lacueva, C.; Izquierdo-Pulido, M.R.; Lamuela-Raventos, M. Liquid chromatographic/electrospray ionization tandem mass spectrometric study of the phenolic composition of cocoa Theobroma cocao. J. Mass Spectrom. 2003, 38, 35-42. [CrossRef] [PubMed]

134. Ruzaidi, A.; Amin, I.; Nawalyah, A.G.; Hamid, M.; Faizul, H.A. The effect of Malaysian cocoa extract on glucose levels and lipid profiles in diabetic rats. J. Ethnopharmacol. 2005, 98, 55-60. [CrossRef] [PubMed]

135. Oracz, J.; Zyzelewicz, D.; Nebesny, E. The Content of Polyphenolic Compounds in Cocoa Beans (Theobroma cacao L.), Depending on Variety, Growing Region, and Processing Operations: A Review. Crit. Rev. Food Sci. Nutition 2015, 55, 1176-1192. [CrossRef]

136. Arranz, S.; Chiva-Blanch, G.; Valderas-Martínez, P.; Medina-Remón, A.; Lamuela-Raventós, R.M.; Estruch, R. Wine, beer, alcohol and polyphenols on cardiovascular disease and cancer. Nutrients 2012, 4, 759-781. [CrossRef]

137. Collin, S.; Jerkovic, V.; Bröhan, M.; Callemien, D. Polyphenols and Beer Quality. In Natural Products; Ramawat, K., Mérillon, J.M., Eds.; Springer: Berlin/Heidelberg, Germany, 2013. [CrossRef]

138. Bianchini, F.; Vainio, H. Wine and resveratrol: Mechanisms of cancer prevention? Eur. J. Can. Prev. 2003, 12, 417-425. [CrossRef]

139. Merkyte, V.; Longo, E.; Windisch, G.; Boselli, E. Phenolic Compounds as Markers of Wine Quality and Authenticity. Foods 2020, 9, 1785. [CrossRef]

140. Carocho, M.; Ferreira, I.C. The role of phenolic compounds in the fight against cancer-A review. Anticancer Agents Med. Chem. 2013, 13, 1236-1258. [CrossRef] [PubMed]

141. Ghasemzadeh, A.; Jaafar, H.Z. Profiling of phenolic compounds and their antioxidant and anticancer activities in pandan (Pandanus amaryllifolius Roxb.) extracts from different locations of Malaysia. BMC Complement. Altern Med. 2013, 13, 341. [CrossRef]

142. De Oliveira, C.B.; Comunello, L.N.; Maciel, E.S.; Giubel, S.R.; Bruno, A.N.; Chiela, E.C.; Lenz, G.; Gnoatto, S.C.; Buffon, A.; Gosmann, G. The inhibitory effects of phenolic and terpenoid compounds from Baccharis trimera in Siha cells: Differences in their activity and mechanism of action. Molecules 2013, 18, 11022-11032. [CrossRef] [PubMed]

143. Senawong, T.; Khaopha, S.; Misunaa, S.; Komaikula, J.; Senawonga, G.; Wongphakhama, P.; Yunchalard, S. Phenolic acid composition and anticancer activity against human cancer cell lines of the commercially available fermentation products of Houttuynia cordata. Sci. Asia 2014, 40, 420-427. [CrossRef]

144. Chen, H.M.; Wu, Y.C.; Chia, Y.C.; Chang, F.R.; Hsu, H.K.; Hsieh, Y.C.; Chen, C.C.; Yuan, S.S. Gallic acid, a major component of Toona sinensis leaf extracts, contains a ROS-mediated anti-cancer activity in human prostate cancer cells. Cancer Lett. 2009, 286, 161-171. [CrossRef]

145. Anantharaju, P.G.; Gowda, P.C.; Vimalambike, M.G.; Madhunapantula, S.V. An overview on the role of dietary phenolics for the treatment of cancers. Nutr. J. 2016, 15, 99. [CrossRef]

146. Lee, Y.J.; Liao, P.H.; Chen, W.K.; Yang, C.Y. Preferential cytotoxicity of caffeic acid phenethyl ester analogues on oral cancer cells. Cancer Lett. 2000, 153, 51-56. [CrossRef]

147. Aguilera, Y.; Martin-Cabrejas, M.A.; González de Mejia, E. Phenolic compounds in fruits and beverages consumed as part of the Mediterranean diet: Their role in prevention of chronic diseases. Phytochem. Rev. 2016, 15, 405-423. [CrossRef]

148. Chen, M.; Meng, H.; Zhao, Y.; Chen, F.; Yu, S. Antioxidant and in vitro anticancer activities of phenolics isolated from sugar beet molasses. BMC Complement. Altern. Med. 2015, 15, 313. [CrossRef]

149. Niero, E.L.; Machado-Santelli, G.M. Cinnamic acid induces apoptotic cell death and cytoskeleton disruption in human melanoma cells. J. Exp. Clin. Cancer Res. 2013, 32, 31. [CrossRef] 
150. Rajendra-Prasad, N.; Karthikeyan, A.; Karthikeyan, S.; Reddy, B.V. Inhibitory effect of caffeic acid on cancer cell proliferation by oxidative mechanism in human HT-1080 fibrosarcoma cell line. Mol. Cell Biochem. 2011, 349, 11-19. [CrossRef]

151. Zhang, X.; Lin, D.; Jiang, R.; Li, H.; Wan, J.; Li, H. Ferulic acid exerts antitumor activity and inhibits metastasis in breast cancer cells by regulating epithelial to mesenchymal transition. Oncol. Rep. 2016, 36, 271-278. [CrossRef] [PubMed]

152. WHO. World Health Report, 1998. Available online: https://www.who.int/whr/1998/media_centre/press_release/en/ (accessed on 19 December 2020).

153. Ramassamy, C. Emerging role of polyphenolic compounds in the treatment of neurodegenerative diseases: A review of their intracellular targets. Eur. J. Pharmacol. 2006, 545, 51-64. [CrossRef] [PubMed]

154. Checkoway, H.; Powers, K.; Smith-Weller, T.; Franklin, G.M.; Longstreth, W.T., Jr.; Swanson, P.D. Parkinson's disease risks associated with cigarette smoking, alcohol consumption, and caffeine intake. Am. J. Epidemiol. 2002, 155, 732-738. [CrossRef] [PubMed]

155. Pan, T.; Fei, J.; Zhou, X.; Jankovic, J.; Le, W. Effects of green tea polyphenols on dopamine uptake and on MPP+-induced dopamine neuron injury. Life Sci. 2003, 72, 1073-1083. [CrossRef]

156. Sackmann, C.; Hallbeck, M. Oligomeric amyloid- $\beta$ induces early and widespread changes to the proteome in human iPSC-derived neurons. Sci. Rep. 2020, 10, 6538. [CrossRef]

157. Bastianetto, S.; Yao, Z.X.; Papadopoulos, V.; Quirion, R. Neuroprotective effects of green and black teas and their catechin gallate esters against beta-amyloid-induced toxicity. Eur. J. Neurosci. 2006, 23, 55-64. [CrossRef]

158. Choi, Y.T.; Jung, C.H.; Lee, S.R.; Bae, J.H.; Baek, W.K.; Suh, M.H.; Park, J.; Park, C.W.; Suh, S.I. The green tea polyphenol (-)-epigallocatechin gallate attenuates beta-amyloid-induced neurotoxicity in cultured hippocampal neurons. Life Sci. 2001, 70, 603-614. [CrossRef]

159. Liguori, I.; Russo, G.; Curcio, F.; Bulli, G.; Aran, L.; Della-Morte, D.; Gargiulo, G.; Testa, G.; Cacciatore, F.; Bonaduce, D.; et al. Oxidative stress, aging, and diseases. Clin. Interv. Aging. 2018, 13, 757-772. [CrossRef]

160. Aryaeian, N.; Sedehi, S.K.; Arablou, T. Polyphenols and their effects on diabetes management: A review. Med. J. Islam Repub Iran. 2017, 31, 134. [CrossRef]

161. Rosillo, M.A.; Alarcón-de-la-Lastra, C.; Sánchez-Hidalgo, M. An update on dietary phenolic compounds in the prevention and management of rheumatoid arthritis. Food Funct. 2016, 7, 2943-2969. [CrossRef] [PubMed]

162. Llano, D.G.; Liu, H.; Khoo, K.; Moreno-Arribas, M.V.; Bartolomé, B. Some New Findings Regarding the Antiadhesive Activity of Cranberry Phenolic Compounds and Their Microbial-Derived Metabolites against Uropathogenic Bacteria. J. Agric. Food Chem. 2019, 67, 2166-2174. [CrossRef] [PubMed]

163. Tarko, T.; Duda-Chodak, A.; Zajac, N. Digestion and absorption of phenolic compounds assessed by in vitro simulation methods. A review. Rocz Panstw Zakl Hig. 2013, 64, 79-84. [PubMed]

164. Quatrin, A.; Rampelotto, C.; Pauletto, R.; Maurer, L.H.; Nichelle, S.N.; Klein, B.; Rodrigues, R.F.; Maróstica Junior, R.M.; Fonseca, B.S.; Menezes, C.R.; et al. Bioaccessibility and catabolism of phenolic compounds from jaboticaba (Myrciaria trunciflora) fruit peel during in vitro gastrointestinal digestion and colonic fermentation. J. Funct. Foods 2020, 65, 103714. [CrossRef]

165. Danneskiold-Samsøe, N.B.; Barros, H.D.d.F.; Santos, R.; Bicas, J.L.; Cazarin, C.B.B.; Madsen, L.; Maróstica Júnior, M.R. Interplay between food and gut microbiota in health and disease. Food Res. Int. 2019, 115, 23-31. [CrossRef]

166. Vitaglione, P.; Donnarumma, G.; Napolitano, A.; Galvano, F.; Gallo, A.; Scalfi, L.; Fogliano, V. Protocatechuic acid is the major human metabolite of cyanidin-glucosides. J. Nutition. 2007, 137, 2043-2048. [CrossRef] [PubMed]

167. Gowd, V.; Karim, N.; Shishir, M.R.I.; Xie, L.; Chen, W. Dietary polyphenols to combat the metabolic diseases via altering gut microbiota. Trends Food Sci. Technol. 2019, 93, 81-93. [CrossRef]

168. Vilela, A.; Cosme, F.; Inês, A. Wine and Non-Dairy Fermented Beverages: A Novel Source of Pro- and Prebiotics. Fermentation 2020, 6, 113. [CrossRef]

169. Saarela, M. Probiotics as ingredients in functional beverages. In Functional and Speciality Beverage Technology; Paquin, P., Ed.; Woodhead Publishing Limited and CRC Press LLC: Cambridge, UK, 2009; pp. 55-70.

170. Soccol, C.R.; De Dea Lindner, J.; Yamaguishi, C.T.; Spier, M.R.; Porto de Souza Vandenberghe, L.; Soccol, V.T. Probiotic nondairy beverages. In Handbook of Plant-Based Fermented Food and Beverage Technology; Hui, Y.H., Ed.; Taylor \& Francis Group: Florence, SC, USA, 2012; pp. 707-728.

171. Silva, S.; Veiga, M.; Costa, E.M.; Oliveira, A.L.S.; Madureira, A.R.; Pintado, M. Nanoencapsulation of Polyphenols towards Dairy Beverage Incorporation. Beverages 2018, 4, 61. [CrossRef]

172. Teng, H.; Chen, L. Polyphenols and bioavailability: An update. Crit. Rev. Food Sci. Nutr. 2019, 59, 2040-2051. [CrossRef] 